\title{
ATP Is Required and Advances Cytokine-Induced Gap Junction Formation in Microglia In Vitro
}

\author{
Pablo J. Sáez, ${ }^{1,2}$ Kenji F. Shoji, ${ }^{1,2}$ Mauricio A. Retamal, ${ }^{3}$ Paloma A. Harcha, ${ }^{1,2}$ \\ Gigliola Ramírez, ${ }^{4}$ Jean X. Jiang, ${ }^{5}$ Rommy von Bernhardi, ${ }^{4}$ and Juan C. Sáez ${ }^{1,2}$ \\ ${ }^{1}$ Departamento de Fisiología, Pontificia Universidad Católica de Chile, Alameda 340, 6513677 Santiago, Chile \\ ${ }^{2}$ Instituto Milenio, Centro Interdisciplinario de Neurociencias de Valparaíso, Pasaje Harrington 287, Playa Ancha, \\ 2360103 Valparaíso, Chile \\ ${ }^{3}$ Departamento de Fisiología, Facultad de Medicina, Clínica Alemana-Universidad del Desarrollo, Las Condes 12438 , \\ 7710162 Santiago, Chile \\ ${ }^{4}$ Departamento de Neurología, Escuela de Medicina, Pontificia Universidad Católica de Chile, Marcoleta 392, 8330024 Santiago, Chile \\ ${ }^{5}$ Department of Biochemistry, University of Texas Health Science Center, 7703 Floyd Curl Drive, San Antonio, TX 78229, USA
}

Correspondence should be addressed to Pablo J. Sáez; pjsaez@uc.cl

Received 4 February 2013; Revised 21 March 2013; Accepted 22 March 2013

Academic Editor: Diego Gomez-Nicola

Copyright (C) 2013 Pablo J. Sáez et al. This is an open access article distributed under the Creative Commons Attribution License, which permits unrestricted use, distribution, and reproduction in any medium, provided the original work is properly cited.

\begin{abstract}
Microglia are the immune cells in the central nervous system. After injury microglia release bioactive molecules, including cytokines and ATP, which modify the functional state of hemichannels (HCs) and gap junction channels (GJCs), affecting the intercellular communication via extracellular and intracellular compartments, respectively. Here, we studied the role of extracellular ATP and several cytokines as modulators of the functional state of microglial HCs and GJCs using dye uptake and dye coupling techniques, respectively. In microglia and the microglia cell line EOC20, ATP advanced the TNF- $\alpha$ /IFN- $\gamma$-induced dye coupling, probably through the induction of IL-1 $\beta$ release. Moreover, TNF- $\alpha / \mathrm{IFN}-\gamma$, but not TNF- $\alpha$ plus ATP, increased dye uptake in EOC20 cells. Blockade of $\mathrm{Cx} 43$ and Panxl HCs prevented dye coupling induced by TNF- $\alpha /$ IFN- $\gamma$, but not TNF- $\alpha$ plus ATP. In addition, IL- 6 prevented the induction of dye coupling and HC activity induced by TNF- $\alpha /$ IFN- $\gamma$ in EOC20 cells. Our data support the notion that extracellular ATP affects the cellular communication between microglia through autocrine and paracrine mechanisms, which might affect the timing of immune response under neuroinflammatory conditions.
\end{abstract}

\section{Introduction}

Microglia are the major immune effectors in the central nervous system (CNS). Under resting conditions, surveillance microglia have a ramified morphology and monitor their local microenvironment $[1,2]$. However, microglia can rapidly become activated in response to diverse stimuli and danger signals, such as ATP or bacterial lipopolysaccharide (LPS) [1-3]. Consistently, microglia are activated in neuroinflammatory conditions and are a common hallmark in many neurodegenerative diseases $[1,2,4]$.

Microglial cell activation includes morphological changes, proliferation, recruitment to the site of injury, and expression of specific proteins including MHC II molecules and cell adhesion molecules $[1,2]$. Activated microglia also release cytokines, including TNF- $\alpha$, IL-1 $\beta$, IL- 6 , IFN- $\gamma$, and other soluble molecules, such as glutamate and ATP [5-9]. Many of these pro-inflammatory molecules act in an autocrine manner and show synergism, increasing the activation of microglia [10-12].

Many studies have focused on ATP release mechanisms and the subsequent receptors activation at the CNS, because they promote the release of other pro-inflammatory molecules, such as TNF- $\alpha$ and IL-1 $\beta$ [13]. These cytokines mediate cell communication and $\mathrm{Ca}^{2+}$ signaling among microglia, as well as among microglia and astrocytes [1416]. Microglia sense extracellular ATP through P2Y and P2X receptors [1]. Under control conditions, microglia express 
$\mathrm{P} 2 \mathrm{X}_{7}$ receptors, which are upregulated as a required step for microglial activation induced by amyloid- $\beta$ peptide $[17$, 18]. Moreover, activation of microglia with LPS increases the intracellular free $\mathrm{Ca}^{2+}$ concentration $\left(\left[\mathrm{Ca}^{2+}\right]_{i}\right)$ and ATP release, through $\mathrm{P}_{2} \mathrm{X}_{7}$ receptors $[17,19,20]$. Accordingly, cytokines that increase $\left[\mathrm{Ca}^{2+}\right]_{i}$ or a calcium ionophore induce microglia activation [21, 22]. These conditions also induce gap junctional communication in primary cultures of rat or mouse microglia $[23,24]$.

Gap junction channels (GJCs) communicate the cytoplasm of contacting cells allowing the direct transfer of ions, second messengers, and other molecules including antigen peptides [25]. Each GJC is formed by the serial docking of two hemichannels (HCs), which are composed of six protein subunits called connexins (Cxs) [25]. It is known that resting microglia express Cxs 32, 36, 43, and 45 and after microglia activation some of them form functional GJCs and HCs [23, 24, 26-28]. Recently, another family of proteins termed pannexins (Panxs) has been found to form functional GJCs and HCs [29]. Like Cx HCs, Panx HCs are permeable to ATP and are activated by increased $\left[\mathrm{Ca}^{2+}\right]_{i}$ and extracellular ATP via P2 receptors [30-32]. Microglia express functional Panxl HCs that contribute to ATP-induced migration and glutamate and ATP release promoting neuronal death [3335]. Under inflammatory conditions, gap junctional communication between cultured astrocytes is reduced, whereas the activity of HCs is increased [35-38]. However, it remains unknown if these opposite changes in GJCs and HCs also occur in microglia, or if extracellular ATP plays a role in this channel-based communication.

In this work, we studied the effect of extracellular ATP on the cytokine-induced gap junctional communication in microglia. To achieve this goal, we used primary cultures of rat microglia and EOC20 cells treated with several cytokines and ATP, either mixed or alone. We propose that TNF$\alpha /$ IFN- $\gamma$ induce gap junctional communication, which might depend on the functional expression of HCs. In addition, we found that extracellular ATP advances the onset of cytokineinduced expression of gap junctional communication, a process that was mediated by IL- $1 \beta$ release and inhibited by IL-6.

\section{Materials and Methods}

2.1. Materials. Modified Eagle's medium (MEM), Dulbecco's modified Eagle's medium (DMEM), F-12 nutrient mixture, fetal bovine serum (FBS), bovine pancreas DNAse I, and trypsin-EDTA were purchased from Gibco (Auckland, NZ, USA). DMSO, HEPES, $\mathrm{H}_{2} \mathrm{O}, \mathrm{LaCl}_{3}\left(\mathrm{La}^{3+}\right)$, ethidium (Etd) bromide, Lucifer yellow dilithium salt (LY, MW: 457,25 Da), rhodamine-dextran (RD, MW: $10 \mathrm{kDa}$ ), adenosine $5^{\prime}$-triphosphate periodate oxidized sodium salt (oATP), ATP disodium salt, probenecid $(\mathrm{Pbc})$, recombinant mouse TNF- $\alpha$, recombinant mouse IL- $1 \beta$, recombinant mouse IFN- $\gamma$, recombinant mouse IL-6, and Ponceau S red were purchased from Sigma-Aldrich (St Louis, MO, USA). Interleukin-1 receptor antagonist (IL-1ra) was from
R\&D (USA). BAPTA-AM was purchased from Molecular Probes (Eugene, Oregon, USA). Penicillin, and streptomycin were obtained from Invitrogen (Carlsbad, CA, USA). D(+)-glucose, sodium hydrogen carbonate $\left(\mathrm{NaHCO}_{3}\right)$ were purchased from Merck (Darmstadt, Germany). ${ }^{10} \mathrm{Panx1}$ mimetic peptide (sequence WRQAAFVDSY) was purchased from SBS Biotech (Beijing, China). Purified rat anti-mouse CD16/CD32 (mouse BD Fc-block) was purchased from BD Pharmingen (San José, CA, USA). F $\left(\mathrm{ab}^{\prime}\right)_{2}$ fragments of a previously characterized polyclonal rabbit anti-Panxl serum used $[39,40]$. The $\mathrm{F}\left(\mathrm{ab}^{\prime}\right)_{2}$ fragments of affinity IgGs purified from the anti-Panxl serum were prepared as previously described [41]. Anti-Cx43 monoclonal antibody was obtained from BD Biosciences (Minneapolis, MN, USA). Cy2 conjugated goat anti-rabbit and Cy3 conjugated goat anti-mouse antibodies were purchased from Jackson Immunoresearch Laboratories Inc. (Indianapolis, IN, USA). EDTA solution, Halt protease inhibitor single-use cocktail, and M-PER mammalian protein extraction reagent were purchased from Thermo Scientific (Rockford, IL, USA). Mount solution fluoromount $\mathrm{G}$ was purchased from Electron Microscopy Sciences (Washington, PA, USA). Images were examined with a confocal laser-scanning microscope which was Olympus Fluoview FV1000 (Tokio, Japan). Cx43 ${ }^{(\mathrm{E} 2)}$ is a rabbit polyclonal antibody that recognizes amino acid residues located at the second extracellular loop of $\mathrm{Cx} 43$ and blocks specifically Cx43 HCs [42].

Bio-Rad protein assay was purchased from Bio-Rad Laboratories (Richmond, CA, USA). SuperSignal kit for enhanced chemiluminescence detection and anti-rabbit antibody conjugated to horseradish peroxidase were purchased from Pierce (Rockford, IL, USA). EOC20 and LADMAC cells were obtained from ATCC (Manassas, VA, USA). Tissue culture flasks (25 and $75 \mathrm{~cm}^{2}$ ) $60 \mathrm{~mm}$ and $100 \mathrm{~mm}$ tissue culture dishes were purchased from Sarstedt (Newton, NC, USA). Twenty four-well plastic dishes were purchased from Nunclon (Roskilde, Denmark).

\subsection{Cell Cultures}

2.2.1. Rat Microglia. Primary cultures of microglia were prepared from neocortex of newborn Sprague Dawley rats, as previously described $[23,24]$. Briefly, meninges were carefully peeled off and cortices were dissected and minced in small pieces. After incubation in $\mathrm{Ca}^{2+}$-free $\mathrm{PBS}$ containing trypsin $(0.5 \%)$ and EDTA $(5 \mathrm{mM})$ at $37^{\circ} \mathrm{C}$ for $30 \mathrm{~min}$, tissue was triturated in presence of DNAse using a Pasteur pipette. Dissociated cells were pelleted and resuspended in MEM medium supplemented with $10 \% \mathrm{FBS}, 100$ units/mL penicillin and $50 \mu \mathrm{g} / \mathrm{mL}$ streptomycin sulfate and plated on plastic culture flasks (Sarstedt). Confluent glial cell mixed cultures were deprived of fresh medium for two weeks to induce microglial cell proliferation. Finally, microglia were harvested from glial cell mixed cultures by differential adhesion and seeded on glass coverslips.

2.2.2. EOC20 Cells. EOC20 cells are a murine microglial cell line derived from $\mathrm{C} 3 \mathrm{H} / \mathrm{HeJ}$ mice, which secrete cytokines and 
present antigens as primary microglia [43]. EOC20 cells were maintained according to ATCC recommendations, using DMEM supplemented with 10\% FBS and 20\% LADMAC conditioned medium (see below). The medium was partially changed twice a week and completely changed once a week until the culture reached confluence. Cells were detached with trypsin-EDTA for $2 \mathrm{~min}$ and mechanical stress, and EOC20 cells were seeded on glass coverslips or tissue culture dishes. Since rat microglia were detached by shaking using an orbital shaker, some experiments were performed with EOC20 cells detached with the same methods of purification used for primary microglia cultures. No differences were observed in the induction of dye coupling between EOC20 cells obtained by the different purification methods (data not shown).

2.2.3. LADMAC Conditioned Medium. The conditioned medium was obtained from LADMAC cells, which are myeloid cells derived from murine bone marrow cells. LADMAC cells are nonadherent cells that secrete colonystimulating-factor-1 (CSF-1) which stimulates cell division in EOC20 cells $[43,44]$. LADMAC cell cultures were maintained in culture in MEM supplemented with 10\% FBS during two weeks. Fresh medium was added every two days duplicating the previous amount of medium. After two weeks in culture, the cell suspension was centrifuged and the CSF-1containing supernatant was filtered, aliquoted, and stored at $-20^{\circ} \mathrm{C}$ until use.

2.3. Dye Transfer Technique. The transference of fluorescent dyes between adjacent cells has been used to monitor the functional state of GJCs in microglia [23, 24, 27]. We tested the intercellular transference of LY using RD as a negative control. Dyes (5\% w/v in $150 \mathrm{mM} \mathrm{LiCl})$ were microinjected by applying current to microglia seeded on glass coverslips $\left(8 \times 10^{5}\right.$ cells/well, in a 24 -multiwell dish $)$ through glass microelectrodes until the impaled cells were fluorescent. Cultures were maintained in F-12 medium supplemented with HEPES and observed with an inverted microscope equipped with Xenon arc lamp illumination and a Nikon B filter (excitation wavelength, 450-490 nm; emission wavelength, above $520 \mathrm{~nm}$ ). Dye transfer was scored at $2 \mathrm{~min}$ injection. The incidence of dye coupling (IDC) was calculated as the percentage of injected cells with dye transfer to one or more neighboring cells by the total number of cells microinjected in each experiment. At least 10 cells were microinjected in each assay. Since cytokine treatments induced HC activity and because that dye uptake from leaking microelectrodes could affect the measurement of fluorescent cells, we use $200 \mu \mathrm{M}$ $\mathrm{La}^{3+}$ in the recording solution. However, no significant differences were observed compared to recording solution without $\mathrm{La}^{3+}$ (data not shown).

2.4. Dye Uptake, $\mathrm{Ca}^{2+}$ Signal Imaging, and Time-Lapse Fluorescence Imaging. To evaluate dye uptake, cells seeded on glass coverslips $\left(8 \times 10^{5}\right.$ cells $\left./ \mathrm{mL}\right)$ were exposed to $5 \mu \mathrm{M}$ ethidium (Etd) bromide with Locke's saline solution (in mM: $154 \mathrm{NaCl} ; 5.4 \mathrm{KCl} ; 2.3 \mathrm{CaCl}_{2} ; 1 \mathrm{mM} \mathrm{MgCl}$; $5 \mathrm{mM}$ glucose;
5 mM HEPES; pH: 7.42) and examined by epifluorescence. Nuclei fluorescence was recorded in regions of interest consisting of 30 different cells per field with a water immersion Olympus 51W1I upright microscope (Melville, NY, USA), as described [45]. The calculation of slope change regression lines was fitted to points before and after treatments using Microsoft (Seattle, WA, USA) Excel. In ATP-induced dye uptake experiments, $500 \mu \mathrm{M}$ ATP was added to recording solution after $5 \mathrm{~min}$ of basal dye uptake.

To evaluate $\mathrm{Ca}^{2+}$ signals, EOC20 cells under control conditions or after treatment were maintained as mentioned above but were loaded for 30 min with $5 \mu \mathrm{M}$ Fura-2 AM in DMEM medium without serum at $37^{\circ} \mathrm{C}$. Loaded cells were washed twice with Locke's solution and time-measurements were performed with an Olympus 51W1I microscope. The acquisition of 340 and $380 \mathrm{~nm}$ excitation wavelengths was every $3 \mathrm{~s}$. Regions of interest consisted in 30 cells per field and analysis were performed using METAFLUOR software.

2.5. Western Blot. Confluent microglia cultures grown in $60 \mathrm{~mm}$ culture dishes $\left(2.4 \times 10^{6}\right.$ cells $)$ were gently rinsed twice with cold $\mathrm{PBS}$ at $4^{\circ} \mathrm{C}, \mathrm{pH} 7.4$ and harvested by scraping with a rubber policeman in a solution containing $5 \mathrm{mM}$ EDTA, Halt, and M-PER protein extraction cocktail according to the manufacturer's instructions. The cellular suspension was sonicated on ice. Proteins were measured in aliquots of cell lysates using the Bio-Rad protein assay. Aliquots of cell lysates $(50 \mu \mathrm{g}$ of protein) were resuspended in Laemli's sample buffer and separated in an $8 \%$ sodium dodecyl sulfate polyacrylamide gel electrophoresis and electrotransferred to nitrocellulose sheets as previously described [24]. Loading equivalences were confirmed by protein staining with Ponceau $\mathrm{S}$ red $(2 \% \mathrm{w} / \mathrm{v}$ in $30 \%$ trichloroacetic acid). Nonspecific protein binding was blocked by incubation of nitrocellulose sheets in $5 \%$ nonfat milk in PBS for $1 \mathrm{~h}$ at room temperature prior to overnight incubation with corresponding antibodies at $4^{\circ} \mathrm{C}$. After several washes with PBS, blots were incubated with the secondary antibody conjugated to horseradish peroxidase for $45 \mathrm{~min}$ at room temperature. Immunoreactivity was detected by enhanced chemiluminescence using the SuperSignal kit according to the manufacturer's instructions.

2.6. Immunofluorescence. Microglia cultured on glass cover slips were fixed with $4 \%$ formaldehyde at room temperature for $30 \mathrm{~min}$ and washed twice with PBS. A blocking solution containing $1 \%$ IgG free BSA, $50 \mathrm{mM} \mathrm{NH}_{4} \mathrm{Cl}$, and $0.05 \%$ Triton X-100 in PBS was used to permeabilize and block unspecific reactive sites. Fc receptors were masked by incubating samples to a solution containing Fc-Block $(1: 100)$ for $45 \mathrm{~min}$ at room temperature. Panxl and $\mathrm{Cx} 43$ were detected with a rabbit polyclonal anti-Panxl $\mathrm{F}\left(\mathrm{ab}^{\prime}\right)_{2}$ fragments [40] and an anti-Cx43 monoclonal antibody, properly diluted with blocking solution, respectively. Cy2 conjugated goat anti-rabbit $(1: 300)$ and $\mathrm{Cy} 3$ conjugated goat anti-mouse $\operatorname{IgGF}\left(\mathrm{ab}^{\prime}\right)_{2}$ Igs fragments for $30 \mathrm{~min}$ at room temperature were used to detect bound primary antibody. Fluoromount G (Electron Microscopy Sciences, Washington, PA, USA) was used as an antifade solution to mount samples. Images 
were examined with a confocal laser-scanning microscope (Olympus, Fluoview FV1000, Tokio, Japan).

2.7. IL-1 $\beta$ ELISA. The level of IL- $1 \beta$ present in the conditioned media of EOC2 0 cells was evaluated with the IL- $1 \beta$ ELISA Ready.Set-Go! (e-Bioscience, San Diego, CA, USA), for performing quantitative enzyme linked immunosorbent assays (ELISA). It has a sensitivity of $8 \mathrm{pg} / \mathrm{mL}$. Standard curve consisted of twofold serial dilutions of the recombinant cytokine. In brief, a 96-well, flat bottom, ELISA-plate (MICROLON, Greiner Bio-One) was coated with capture antibody in coating buffer overnight at $4^{\circ} \mathrm{C}$. The plate was washed 5 times with PBS-0.05\% Tween-20 in ELx50 Biokit, a 96-well bioelisa washer, and Rhe plate was blocked with $200 \mu \mathrm{L}$ of assay diluent at room temperature for $1 \mathrm{~h}$, washed as mentioned, and $100 \mu \mathrm{L}$ of standard IL1 $\beta$ and samples were incubated at $4^{\circ} \mathrm{C}$ overnight. Then, the plate was washed and $100 \mu \mathrm{L}$ of detection antibody for IL-1 $\beta$ was added and incubated at room temperature by $1 \mathrm{~h}$, washed 5 times, incubated with $100 \mu \mathrm{L}$ Avidin-HRP at room temperature for $30 \mathrm{~min}$, washed 7 times, added $100 \mu \mathrm{L}$ substrate solution, and stopped the reaction with $50 \mu \mathrm{L}$ of $1 \mathrm{M} \mathrm{H}_{3} \mathrm{PO}_{4}$. The plate was read at $450 \mathrm{~nm}$, with reference at $570 \mathrm{~nm}$.

2.8. Treatments. Microglia were seeded $48 \mathrm{~h}$ before dye transfer, dye uptake, or immunofluorescence experiments in 24-well plastic dish containing $500 \mu \mathrm{L}$ of culture medium. For Western blot experiments, cells were seeded in $60 \mathrm{~mm}$ plastic dishes in $3 \mathrm{~mL}$ of culture medium. After $48 \mathrm{~h}$ under control conditions microglia were treated with $1 \mathrm{mM}$ ATP or $1 \mathrm{ng} / \mathrm{mL}$ TNF- $\alpha$, IFN- $\gamma$, IL- $1 \beta$ either alone or mixed. Cytokines were added simultaneously and ATP was added $2 \mathrm{~h}$ before measurement and is referred as cytokine(s) plus ATP. Treatment with 1,10 , or $50 \mathrm{ng} / \mathrm{mL}$ IL-6, $20 \mathrm{ng} / \mathrm{mL}$ IL1ra, $300 \mu \mathrm{M}$ oATP, $200 \mu \mathrm{M} \mathrm{La}^{3+}, 1: 500 \mathrm{Cx} 43^{(\mathrm{E} 2)}$ antibody or $200 \mu \mathrm{M}{ }^{10}$ Panxl was simultaneous to cytokine treatment. We used $50 \mu \mathrm{M}$ of $\beta$-GA for acute GJCs blocking (Figure S1, see Supplementary Materials available online at http://dx.doi.org/10.1155/2013/216402). To avoid disruption of cell adhesion with BAPTA, the medium was replaced with culture medium of parallel cultures treated at the same time to maintain the soluble factor released from microglia.

2.9. Statistical Analysis. Data are presented as mean \pm SEM, as percentage of the control condition; $n$ represents the number of independent experiments. For statistical analysis, each treatment was compared with its respective control and significance was determined using one-way ANOVA followed by Dunn's test comparing all treatments against the control condition. To observe differences between microglia and EOC20 cells responses we used a two-way ANOVA.

\section{Results}

3.1. The Onset of the Cytokine-Induced Increase in Gap Junctional Communication in Cultured Microglia Is Advanced by ATP and Delayed by IFN- $\gamma$. Calcium ionophore and proinflammatory molecules promote a transient expression of functional GJCs in microglia [23, 24, 27]. Since extracellular ATP, TNF- $\alpha$, and IFN- $\gamma$ play a relevant role in microglial cell responses $[3,7,46]$ and affect the $\left[\mathrm{Ca}^{2+}\right]_{i}[47-49]$, we decided to evaluate if these compounds affect the intercellular communication via GJCs in both primary cultures of rat microglia and EOC20 cells.

After $48 \mathrm{~h}$ of subculture under control conditions, microglia were treated as indicated in Methods (Figure S1a). Both cell types presented rather homogeneous morphological features (Figures 1(a) and 1(b)) and very low incidence of Lucifer yellow (LY) transfer to neighboring cells (Figures 1(a) and 1(b)). Under these conditions, the incidence of dye coupling (I.D.C) remained low for up to $12 \mathrm{~h}$ of culture in both cell types (Figure 1, Supporting information Table S1). In addition, intercellular transfer of rhodamine-dextran (RD, $\sim 10 \mathrm{kDa}$ ), which due to its high molecular weight cannot permeate through GJCs, was not observed (Figure S2a). This result indicates that intercellular LY transfer ocurred via GJCs and not through other cell-cell communication pathway, such as cytoplasmic bridges. Moreover, microglia treated either with $1 \mathrm{mM}$ ATP, $1 \mathrm{ng} / \mathrm{mL}$ TNF- $\alpha, 1 \mathrm{ng} / \mathrm{mL}$ IFN- $\gamma$, or $1 \mathrm{ng} / \mathrm{mL}$ IL-1 $\beta$ showed only a slight increase in IDC, which was not statistically different from that of control cells $(P>0.05$ : Supporting information Table S1). However, treatment with mixes of these molecules during different time periods caused a significant and transient increase in IDC; the dye transfer data is expressed as percentage of the corresponding control condition (Figures 1(e) and 1(f)). In both cell types, treatment with $1 \mathrm{ng} / \mathrm{mL}$ TNF- $\alpha$ plus $1 \mathrm{ng} / \mathrm{mL} \mathrm{IFN-} \gamma$ (from now and on referred as TNF- $\alpha /$ IFN- $\gamma$ ) increased the IDC, reaching a maximum response at around $9 \mathrm{~h}$ after treatment (IDC in EOC20 cells: $574 \pm 36 \%$ of control; rat microglia, $552 \pm 36 \%$ of control; Mean \pm SEM; $n=5$ ) as previously described [23].

We also studied if extracellular ATP affects TNF- $\alpha /$ IFN$\gamma$-induced dye coupling. To this end, cells were treated with these cytokines and then exposed to ATP for $2 \mathrm{~h}$. In both cell types, treatment with TNF- $\alpha /$ IFN- $\gamma$ plus ATP induced a transient increase in IDC, which was maximal at around $5 \mathrm{~h}$ (EOC20 cells: $517 \pm 94 \%$ of control; rat microglia: $506 \pm 42 \%$ of control, $n=5$ ). The amplitude and duration (magnitude) of the response was similar to that induced by TNF- $\alpha / \mathrm{IFN}-\gamma$, but occurred $4 \mathrm{~h}$ earlier (Figure 1(e)).

Since IFN- $\gamma$ potentiates TNF- $\alpha$-induced dye coupling in antigen presenting cells, including dendritic cells, microglia and monocytes/macrophages $[23,50,51]$, we tested whether ATP induces a similar effect on microglia. In agreement with this possibility, cells treated with TNF- $\alpha$ plus ATP showed maximal IDC with similar amplitude (EOC20 cells: $529 \pm 12 \%$ of control; rat microglia: $534 \pm 70 \%$ of control; $n=6$; Figure 1 ) to that induced by TNF- $\alpha / \mathrm{IFN}-\gamma$ plus ATP, but occurred $1.5 \mathrm{~h}$ earlier (at $\sim 3.5 \mathrm{~h}$ versus $5 \mathrm{~h}$; Figures $1(\mathrm{e})$ and $1(\mathrm{f})$ ). As mentioned before intercellular transfer of LY was enhanced in primary microglia or EOC2 0 cells treated with TNF- $\alpha$ plus ATP (Figures 1(c) and 1(d)). However, intercellular transfer of RD was not observed, ruling out the formation of cytoplasmic bridges or vesicular mediated dye transfer in each condition (Figure S2). Microglia treated with IFN- $\gamma$ plus ATP did not increase dye coupling at $3.5 \mathrm{~h}$ (EOC20 cells: $167 \pm 97 \%$ of 


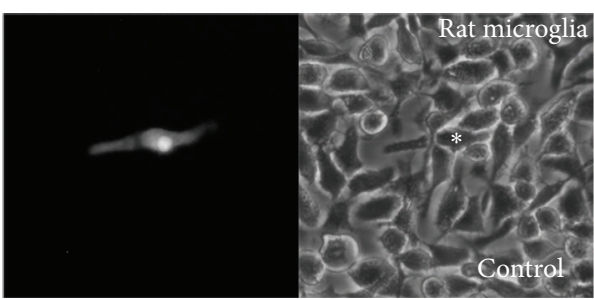

(a)

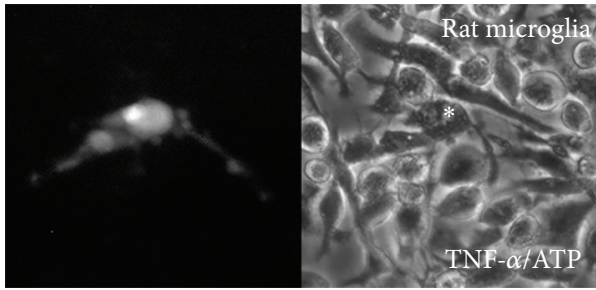

(c)

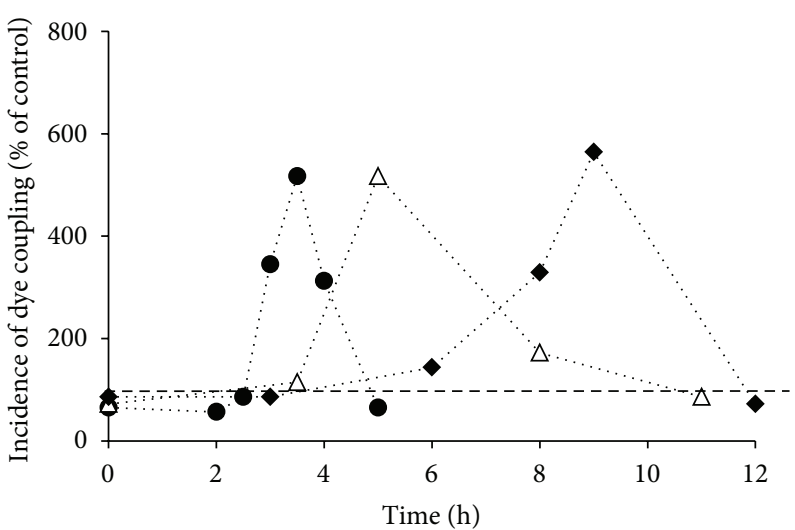

e. TNF- $\alpha /$ ATP

$\Delta$ TNF- $\alpha /$ IFN $-\gamma /$ ATP

-. TNF- $\alpha /$ IFN $-\gamma$

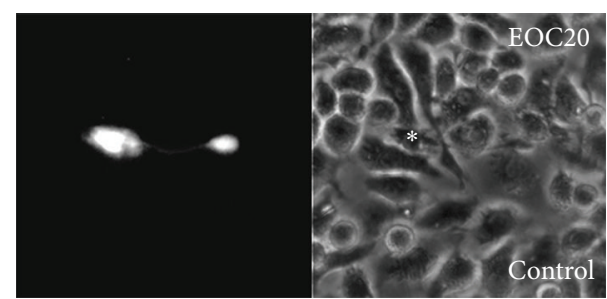

(b)

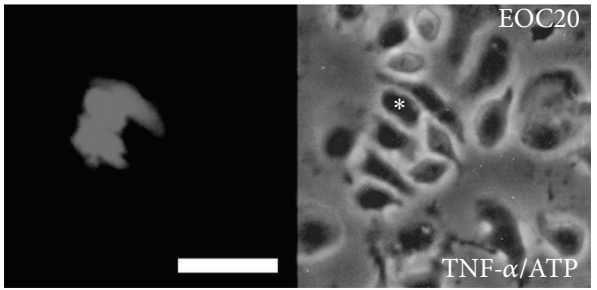

(d)

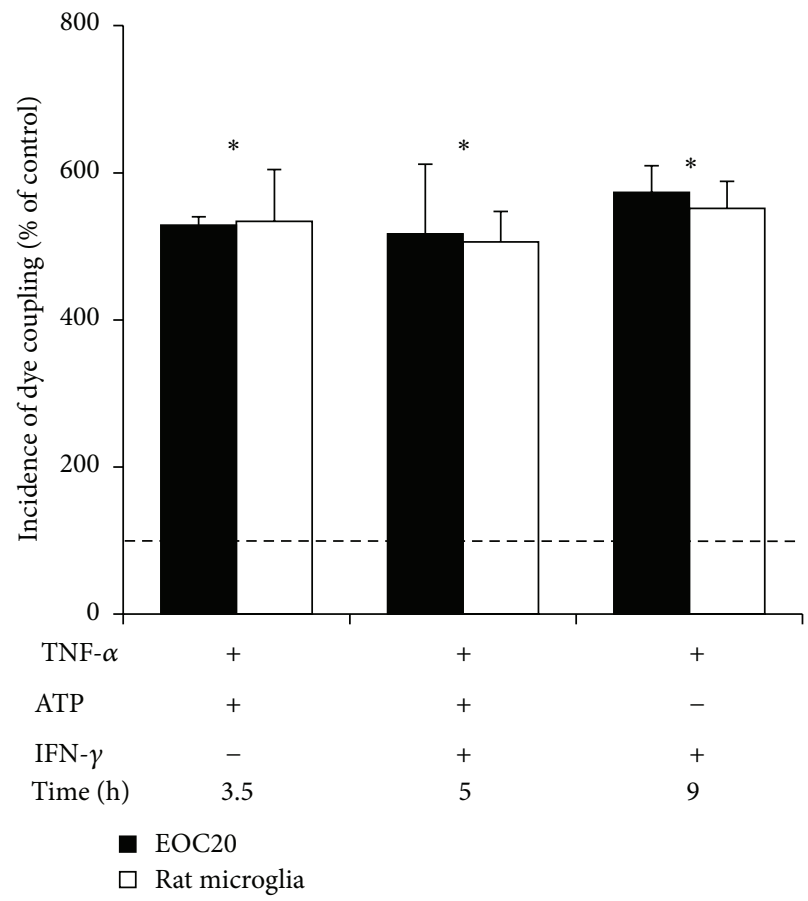

(f)

FIGURE 1: ATP advances the onset of TNF- $\alpha$ /IFN- $\gamma$-induced dye coupling. (a) -(d) Dye transfer was evaluated 2 min after Lucifer yellow (LY) microinjection in a single cell (indicated with an asterisk). Representative pictures of LY transfer in rat microglia (a), (c) or EOC20 cells (b), (d) under control condition or after TNF- $\alpha$ plus ATP (TNF- $\alpha$ /ATP) treatment for $3.5 \mathrm{~h}$, as indicated. Phase contrasts of each micrograph are shown at the right panels. Scale bar: $20 \mu \mathrm{m}$. (e) Time course of the incidence of dye coupling (IDC) as percentage of IDC in EOC20 cells under control conditions (dashed line) or after treatment with TNF- $\alpha$ plus ATP (black circles), TNF- $\alpha /$ IFN- $\gamma$ plus ATP (white triangles), or TNF- $\alpha /$ IFN- $\gamma$ (black diamonds). Each point corresponds to the mean of 3 independent experiments. (f) Graph showing the maximum values of IDC after treatment with TNF- $\alpha$ plus ATP for $3.5 \mathrm{~h}$, TNF- $\alpha /$ IFN- $\gamma$ plus ATP for $5 \mathrm{~h}$, or TNF- $\alpha /$ IFN- $\gamma$ for $9 \mathrm{~h}$. ${ }^{*} P<0.05$ versus control condition. Each bar represents the mean $\pm \mathrm{SEM}, n=6$. No significant differences were observed when comparing microglia and EOC20 cells responses to different treatment in dye transfer assays. Concentrations: $1 \mathrm{ng} / \mathrm{mL}$ TNF- $\alpha ; 1 \mathrm{mM}$ ATP; $1 \mathrm{ng} / \mathrm{mL}$ IFN- $\gamma$.

control; rat microglia: $210.8 \pm 51.3 \%$ of control) or other times ( 2 and $5 \mathrm{~h}$, data not shown).

3.2. The Increase of Gap Junctional Communication Induced by TNF- $\alpha$ Plus ATP Requires an Increase of $\left[\mathrm{Ca}^{2+}\right]_{i}$ via
Activation of P2X Receptors and Is Prevented by IL-6. Eugenín et al. (2001) described that dye coupling between microglia treated for $9 \mathrm{~h}$ with TNF- $\alpha / \mathrm{IFN}-\gamma$ is inhibited by $\beta$-GA. In EOC2 0 cells treated with TNF- $\alpha / \mathrm{IFN}-\gamma$, we observed a similar acute blockade with $\beta$-GA (data not shown). 


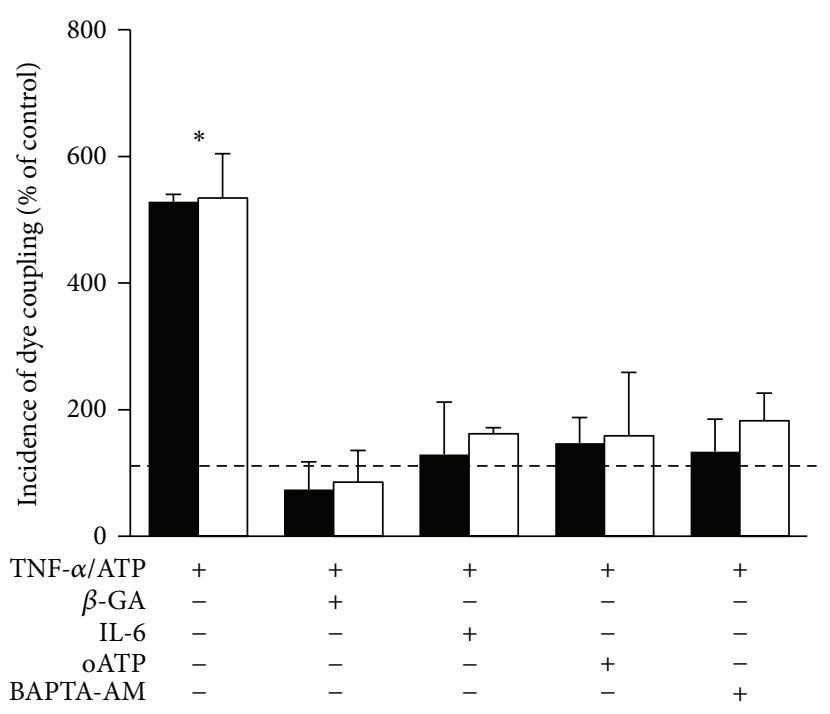

(a)

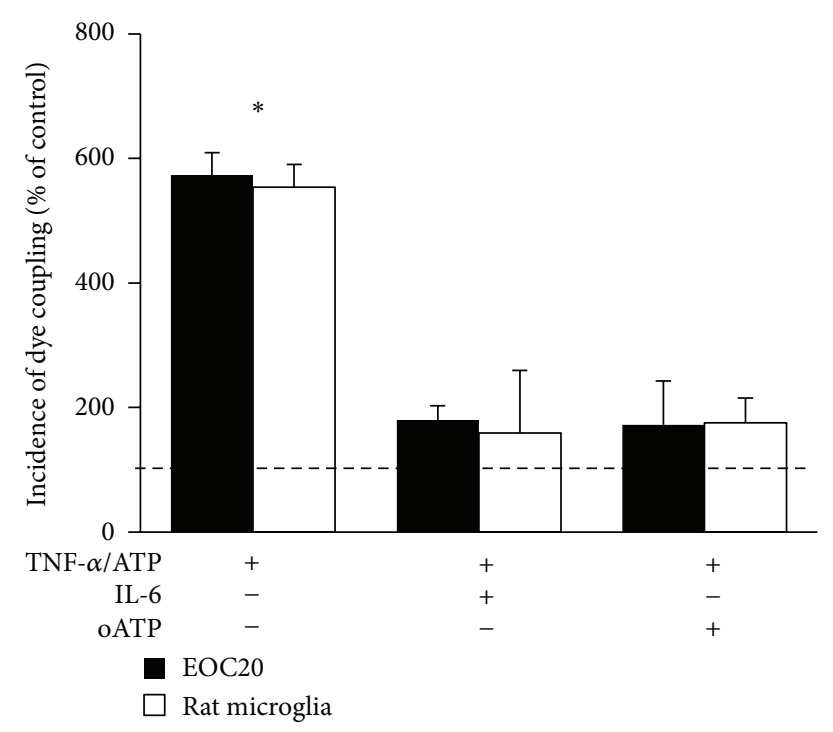

(b)

FIGURE 2: IL-6, intracellular calcium chelation, and P2X inhibition prevent the induction of gap junctional communication promoted by TNF- $\alpha$ plus ATP or TNF- $\alpha /$ IFN- $\gamma$. (a) Graph showing the effect of acutely applied $50 \mu \mathrm{M} 18$ - $\beta$-glycyrrhetinic acid ( $\beta$-GA) or pretreatment with $10 \mathrm{ng} / \mathrm{mL}$ interleukin-6 (IL-6), $300 \mu \mathrm{M}$ oxidized ATP (oATP), or $10 \mu \mathrm{M}$ BAPTA-AM on the incidence of dye coupling (IDC) of microglia treated for $3.5 \mathrm{~h}$ with TNF- $\alpha$ plus ATP. (b) Graph showing the effect of $50 \mathrm{ng} / \mathrm{mL}$ IL- 6 or $300 \mu \mathrm{M}$ oATP over the IDC of microglia treated for $9 \mathrm{~h}$ with TNF- $\alpha /$ IFN $-\gamma$. Data is expressed as a percentage of IDC under control conditions (dashed line). ${ }^{*} P<0.05$ versus control condition. Each bar represents the mean \pm SEM, $n=5$. No significant differences were observed when comparing microglia and EOC20 cells responses to different treatment in dye transfer assays.

In addition, application of $50 \mu \mathrm{M} \beta$-GA for 5 min completely abolished dye coupling induced by TNF- $\alpha$ plus ATP (IDC in EOC20 cells: $74 \pm 44 \%$ of control; rat microglia: $86 \pm 50 \%$ of control; $n=5$; Figure 2(a)).

Since microglia treated with purinergic agonists release IL-6 [52], and this cytokine prevents the increase of dye coupling induced by TNF- $\alpha /$ IL-1 $\beta$ in dendritic cells [50], we decided to test if IL- 6 prevents induction of dye coupling in microglia treated with TNF- $\alpha$ plus ATP. In cell cultures treated simultaneously with $10 \mathrm{ng} / \mathrm{mL}$ IL- 6 plus TNF- $\alpha$ and then treated with ATP for $3.5 \mathrm{~h}$, the IDC was low (EOC20 cells: $130 \pm 83 \%$ of control; rat microglia: $162 \pm 10 \%$ of control; $n=4)$ similar to the results obtained under control conditions (Figure 2(a)). Similarly, the TNF- $\alpha /$ IFN$\gamma$-induced dye coupling was prevented by IL-6 (Figure 2(b)). This inhibitory effect was IL-6 concentration-dependent (1, 10 , and $50 \mathrm{ng} / \mathrm{mL}$, data not shown). The maximal effect was induced by $50 \mathrm{ng} / \mathrm{mL}$ IL-6 (EOC20: $180 \pm 23 \%$ of control; rat microglia: $159 \pm 100 \%$ of control; $n=4$; Figure 2(b)).

Since microglia express several P2X and P2Y receptors [3], the possible involvement of purinergic receptors in the TNF- $\alpha /$ IFN- $\gamma$-induced dye coupling in microglia treated with oxidized-ATP (oATP), an inhibitor of P2X receptors [53], was studied. Coapplication of $300 \mu \mathrm{M}$ oATP prevented dye transfer induced by TNF- $\alpha$ plus ATP (IDC in EOC20 cells: $147 \pm 41 \%$ of control; rat microglia: $159 \pm 100 \%$ of control; $n=5$; Figure $2(\mathrm{a})$ ) or by TNF- $\alpha / \mathrm{IFN}-\gamma$ (IDC in EOC20: $172 \pm 70 \%$ of control; rat microglia: $176 \pm 40 \%$ of control; $n=5$; Figure 2(b)). Moreover, cells treated with TNF- $\alpha$ plus $1 \mathrm{mM}$ ADP, a P2Y agonist [53], for $3.5 \mathrm{~h}$ did not show changes in dye coupling (IDC in EOC20 cells: $168 \pm 84 \%$ of control, $n=3$ ), suggesting that P2Y receptors are not involved in ATPinduced gap junctional communication in microglia.

Since activation of $\mathrm{P} 2$ receptors promotes a rise in $\left[\mathrm{Ca}^{2+}\right]_{i}$ in microglia [54], we tested if this response was related to the increase in dye coupling induced by TNF- $\alpha$ plus ATP. Cells were loaded with BAPTA, a $\mathrm{Ca}^{2+}$ chelator, and then washed and the extracellular medium was replaced with conditioned medium of cultures treated in parallel with TNF$\alpha$ for 90 min to maintain the culture conditions as before loading with BAPTA. In these cells, treatment with TNF$\alpha$ plus ATP did not increase dye coupling (IDC in EOC20 cells: $134 \pm 51 \%$ of control; rat microglia: $183 \pm 44 \%$ of control; $n=5$; Figure 2(a)). In addition, we observed that EOC20 cells treated with TNF- $\alpha$ plus ATP present increased $\mathrm{Ca}^{2+}$ signal, compared to cells under control conditions (Figure S3a). Interestingly, IL-6 prevented this rise in the $\mathrm{Ca}^{2+}$ signal (Figure S3b), suggesting that IL-6 might regulate the purinergic signaling in EOC20 cells.

3.3. IL-1 $\beta$ Released by Activated Microglia Mediates the TNF$\alpha /$ IFN- $\gamma$-Induced Dye Coupling in EOC20 Cells. Since activated microglia release IL-1 $\beta$ and its natural antagonist IL-1ra $[7,55]$, we studied possible involvement of these molecules in the transient increase in dye coupling induced by TNF- $\alpha$ plus ATP or TNF- $\alpha / \mathrm{IFN}-\gamma$. Coapplication of $20 \mathrm{ng} / \mathrm{mL}$ IL-1ra significantly prevented the increase in IDC induced by TNF$\alpha$ plus ATP (in EOC20 cells: $217 \pm 36 \%$ of control, $n=4$ ) or TNF- $\alpha /$ IFN- $\gamma$ (in EOC20 cells: $241 \pm 53 \%$ of control, $n=4$; 


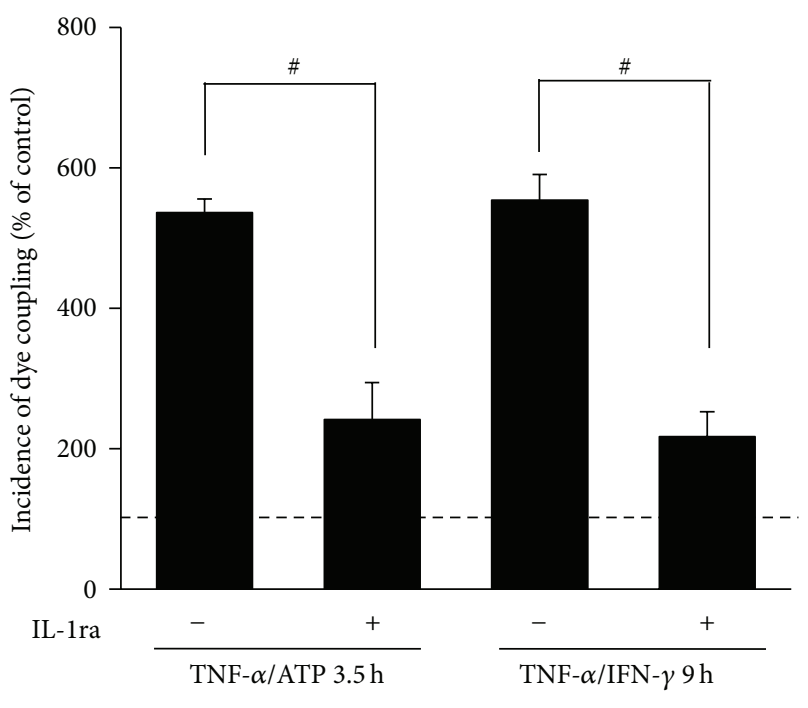

(a)

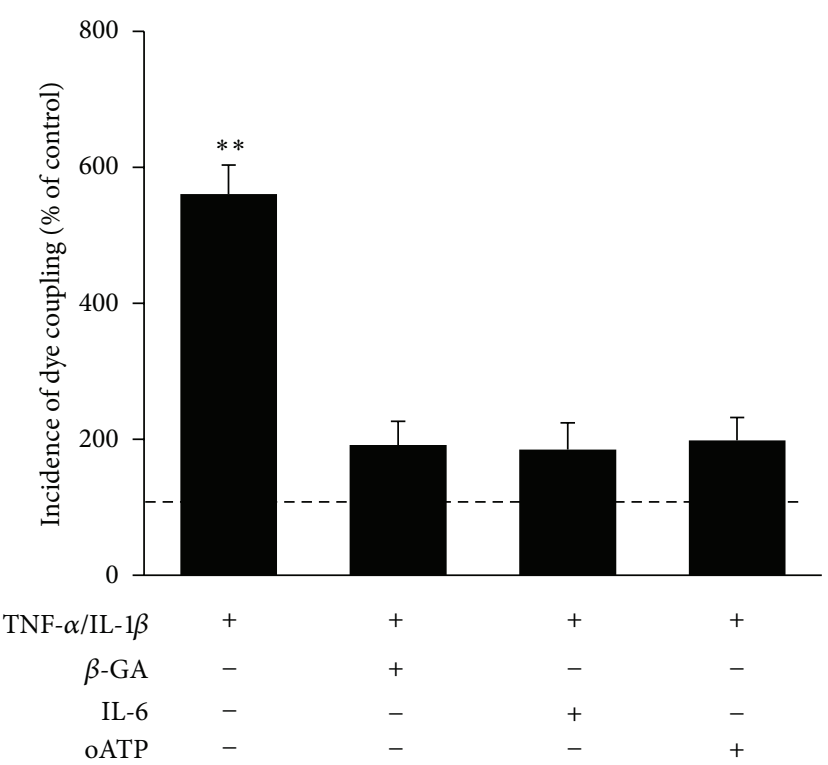

(b)

FIGURE 3: IL-1 $\beta$ mediates gap junctional communication induced by pro-inflammatory molecules. (a) Effect of $20 \mathrm{ng} / \mathrm{mL}$ IL-1 receptor agonist (IL-1ra) over LY transfer in EOC20 cells treated with TNF- $\alpha$ plus ATP for $3.5 \mathrm{~h}$ or with TNF- $\alpha / \mathrm{IFN}-\gamma$ for $9 \mathrm{~h}$. ${ }^{\#} P<0.05$ between indicated treatments. Each bar represents the mean \pm SEM, $n=4$. (b) The effect of $50 \mu \mathrm{M} 18$ - $\beta$-glycyrrhetinic acid $(\beta$-GA) acutely applied or treatment with $10 \mathrm{ng} / \mathrm{mL}$ interleukin-6 (IL-6) or $300 \mu \mathrm{M}$ oxidized ATP (oATP) over LY transfer in EOC20 cells treated with TNF- $\alpha / \mathrm{IL}-1 \beta$ for $9 \mathrm{~h}$ is also shown. Each bar represents the mean \pm SEM, $n=4$, and corresponds to the percentage of incidence of dye coupling under control conditions (dashed line). ${ }^{*} P<0.05,{ }^{* *} P<0.01$ versus control condition.

Figure 3(a)). Moreover, EOC20 cells showed an increase in IL- $1 \beta$ release after TNF- $\alpha$ plus ATP or TNF- $\alpha / \mathrm{IFN}-\gamma$ stimulation, which was partially prevented by IL-6 (Figure S4). Consistent with the involvement of IL- $1 \beta$ in the above dye coupling response induced by both pro-inflammatory molecules, exogenous application of $1 \mathrm{ng} / \mathrm{mL}$ IL- $1 \beta$ plus TNF$\alpha$ induced a similar response than that elicited by TNF$\alpha$ plus ATP or TNF- $\alpha /$ IFN- $\gamma$ (Figure 3(b)). EOC20 cells treated with TNF- $\alpha / \mathrm{IL}-1 \beta$ showed a transient increase in dye coupling (data not shown), reaching a maximal IDC at $\sim 9 \mathrm{~h}$ of treatment (EOC20 cells: $560 \pm 43 \%$ of control, $n=$ 4; Figure 3(b)). The TNF- $\alpha /$ IL-1 $\beta$-induced dye coupling was drastically reduced by the acute application of $50 \mu \mathrm{M} \beta$-GA (IDC in EOC20 cells: $192 \pm 35 \%$ of control, $n=4$ ) and prevented by $10 \mathrm{ng} / \mathrm{mL}$ IL- 6 (in EOC20 cells: $185 \pm 40 \%$ of control, $n=4$ ) or $300 \mu \mathrm{M}$ oATP (in EOC20 cells: $198 \pm$ $34 \%$ of control, $n=4$ ) coapplied with the two cytokines (Figure 3(b)). However, treatment with IL-1 $\beta$ did not increase dye coupling in EOC20 cells (data not shown).

\subsection{TNF- $\alpha /$ IFN- $\gamma$ but Not TNF- $\alpha$ Plus ATP Increases Plasma} Membrane Permeability in EOC20 Cells. Astrocytes treated with TNF- $\alpha /$ IL-1 $\beta$ for $24 \mathrm{~h}$ [38] and microglia treated with LPS (or TNF- $\alpha$ ) for $24 \mathrm{~h}$ showed an increased HC activity $[28,35,56-58]$. Using the ethidium (Etd) uptake assay to evaluate the functional state of HCs located at the cell surface $[38,59]$, we studied if TNF- $\alpha$ or ATP affects the membrane permeability of microglia cells. In EOC20 cells, Etd uptake evaluated with time-lapse measurements showed no significant differences after treatment with TNF- $\alpha$ plus ATP as compared to untreated cells (Figure S5). In control conditions, Etd uptake was partially blocked by $200 \mu \mathrm{M} \mathrm{La}^{3+}$ (after $\mathrm{La}^{3+}: 45 \pm 11 \%$ of control, $n=5$ ), a Cx HC blocker that does not affect Panx HCs [31] and by $10 \mu \mathrm{M}$ carbenoxolone (Cbx) (after Cbx: $36 \pm 15 \%$ of control, $n=5$ ), which at this concentration inhibits mainly Panx HCs [60]. A slight, but not statistically significant increase in Etd uptake was recorded after $3.5 \mathrm{~h}$ treatment with TNF- $\alpha$ plus ATP (134 \pm $25 \%$ of control, $n=5$ ) and was inhibited by $\mathrm{La}^{3+}$ (after $\mathrm{La}^{3+}: 47 \pm 8 \%$ of control, $n=5$ ) or Cbx (after Cbx: $38 \pm$ $8 \%$ of control, $n=5$ ), suggesting an upstream cross talk between $\mathrm{Cx}$ and Panx HCs. In addition, $10 \mathrm{ng} / \mathrm{mL}$ IL- 6 did not affect the response induced by TNF- $\alpha$ plus ATP treatment for $3.5 \mathrm{~h}$ (Etd uptake rate: $141 \pm 16 \%$ of control, $n=5$; Figure S5b). In contrast, after treatment with TNF- $\alpha / \mathrm{IFN}-\gamma$ for $9 \mathrm{~h}$, a statistically significant increase in the Etd uptake rate compared to the control condition was detected (Figure 4). In EOC20 cells cultured for $9 \mathrm{~h}$ under control conditions the Etd uptake rate remained low and was partially blocked by $\mathrm{La}^{3+}$ ( $57 \pm 17 \%$ of control, $n=5$; Figures 4 (a) and 4(e)) or Cbx ( $34 \pm 4 \%$ of control, $n=5$; Figure 4(e)). However, cells treated with TNF- $\alpha /$ IFN $-\gamma$ for $9 \mathrm{~h}$ showed a prominent increase in Etd uptake ( $237 \pm 25 \%$ of control, $n=5$ ) that was drastically reduced by $\mathrm{La}^{3+}(51 \pm 12 \%$ of control, $n=5$; Figures $4(\mathrm{a})$ and $4(\mathrm{e}))$ or Cbx ( $76 \pm 9 \%$ of control, $n=5$; Figure 4(e)). A similar increase in dye uptake was found after treatment with TNF$\alpha / \mathrm{IL}-1 \beta$ for 9 h (Etd uptake rate: $197 \pm 41 \%$ of control, $n=3$ ), which was also reduced by $\mathrm{La}^{3+}$ (Etd uptake rate: $105 \pm 4 \%$ 


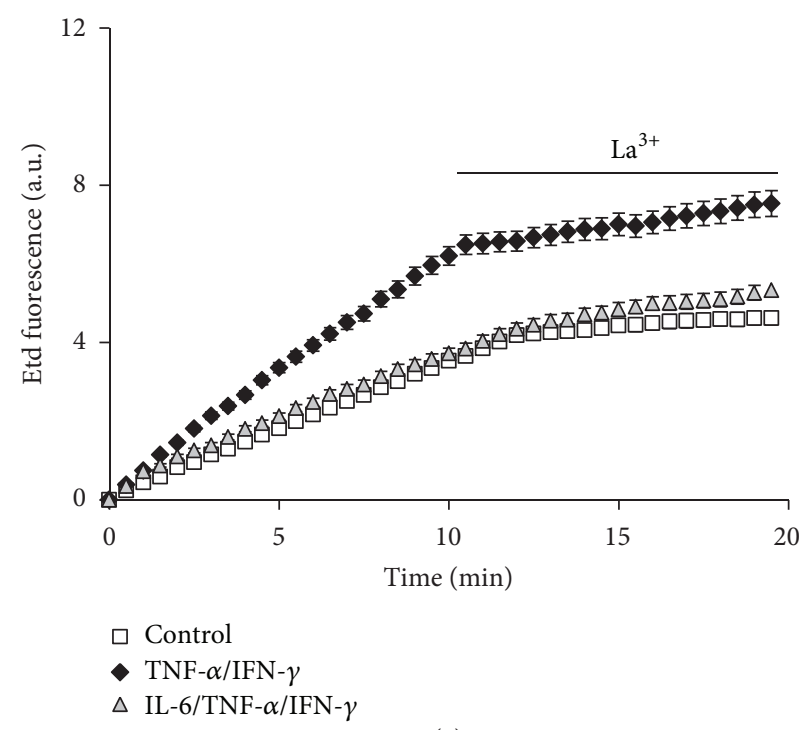

(a)

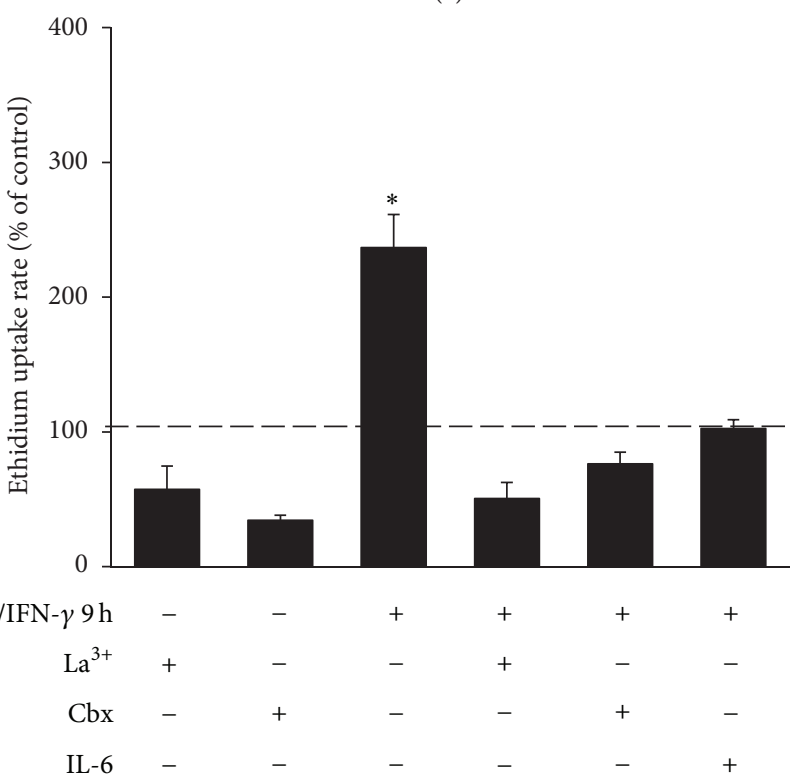

(e)

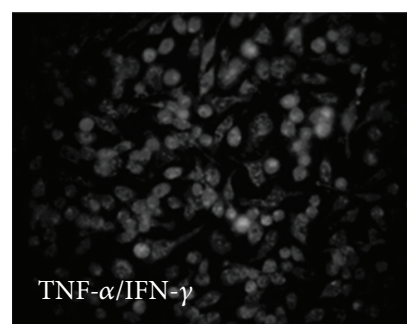

(b)

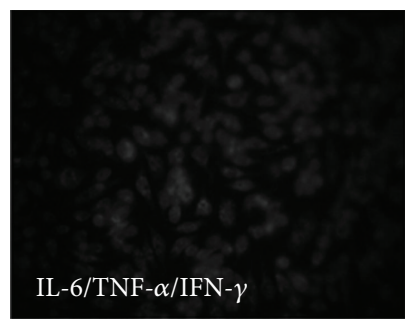

(c)

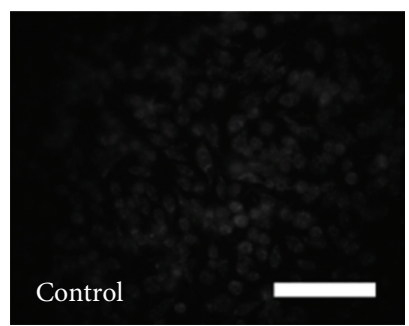

(d)

FIGURE 4: TNF- $\alpha$ /IFN- $\gamma$ induces membrane permeabilization in EOC20 cells. (a) Time-lapse measurements of ethidium (Etd) uptake in EOC20 cells under control conditions (white squares), or after treatment with TNF- $\alpha /$ IFN- $\gamma$ (black diamonds) or IL-6/TNF- $\alpha /$ IFN- $\gamma$ (gray triangles) for $9 \mathrm{~h}$. Each value represents the mean \pm SEM of 30 cells. After $10 \mathrm{~min}$ of basal uptake, $200 \mu \mathrm{M} \mathrm{La}{ }^{3+}$ was applied to the bath. (b)-(d) Representative fluorescence micrographs of Etd uptake after $10 \mathrm{~min}$ of Etd uptake under indicated treatments, previous to La ${ }^{3+}$ application. Scale bar: $100 \mu \mathrm{m}$. (e) Graph showing the acute effect of $200 \mu \mathrm{M} \mathrm{La}^{3+}, 10 \mu \mathrm{M}$ carbenoxolone (Cbx), or pretreatment with $50 \mathrm{ng} / \mathrm{mL}$ of interleukin-6 (IL-6) Etd uptake rate expressed as percentage of control conditions (dashed line) in EOC20 cells treated with TNF- $\alpha /$ IFN- $\gamma$ for $9 \mathrm{~h}$. Each bar corresponds to the mean \pm SEM, $n=5 .{ }^{*} P<0.05$ versus control condition.

of control, $n=3$ ). Moreover, coapplication of $50 \mathrm{ng} / \mathrm{mL}$ IL6 with TNF- $\alpha / \mathrm{IFN}-\gamma$ prevented the Etd uptake rate increase in cells treated just with TNF- $\alpha / \mathrm{IFN}-\gamma(96 \pm 67 \%$ of control, $n=5$; Figure $4(\mathrm{e}))$. In the latter conditions, the Etd uptake rate was slightly reduced by $\mathrm{La}^{3+}(48 \pm 8 \%$ of control, $n=5)$.

3.5. Extracellular ATP Increases the Plasma Membrane Permeability in EOC20 Cells. Extracellular ATP, in the millimolar range, induces membrane permeabilization in many cell types, including microglia $[61,62]$. Similarly, ATP permeabilizes macrophages in a Panxl-dependent way [31]. We tested the effect of $2 \mathrm{mM}$ ATP on Etd uptake in EOC20 cells, as previously observed in macrophages and described by others $[31,63]$. A rapid increase in Etd uptake rate (expressed as $\%$ of control) was induced by the acute application of $2 \mathrm{mM}$ ATP $(529 \pm 84 \%$ of basal uptake, $n=5)$ to cells cultured for $3.5 \mathrm{~h}$ under control conditions (Figures 5(a) and 5(b)). This response was drastically blocked by $10 \mu \mathrm{M}$ Cbx $(218 \pm 81 \%$ of basal uptake, $n=5$; Figure $5(\mathrm{a}))$, as well as by $50 \mu \mathrm{M} \beta-\mathrm{GA}$, 


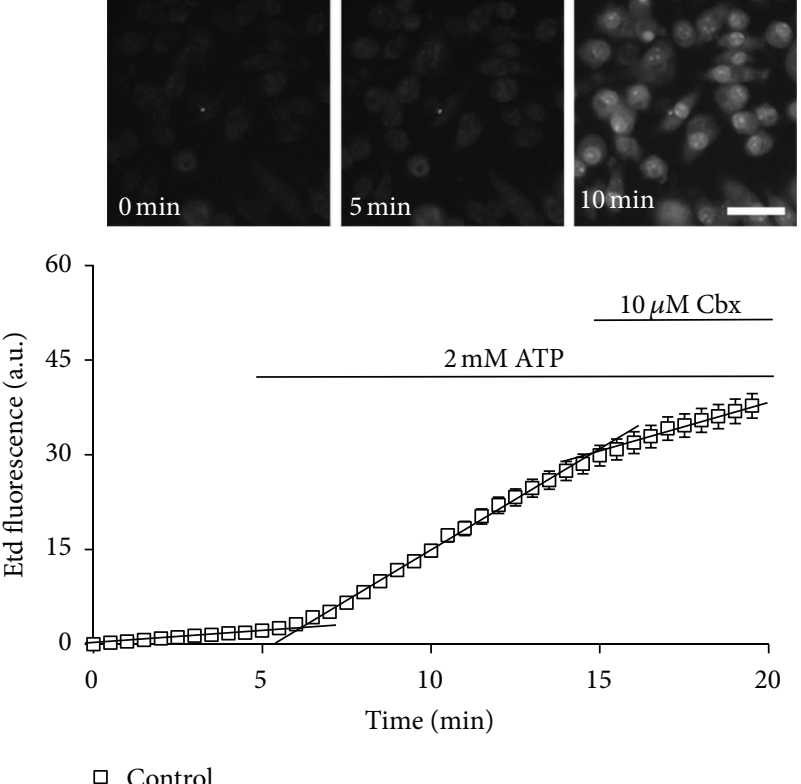

$\square$ Control

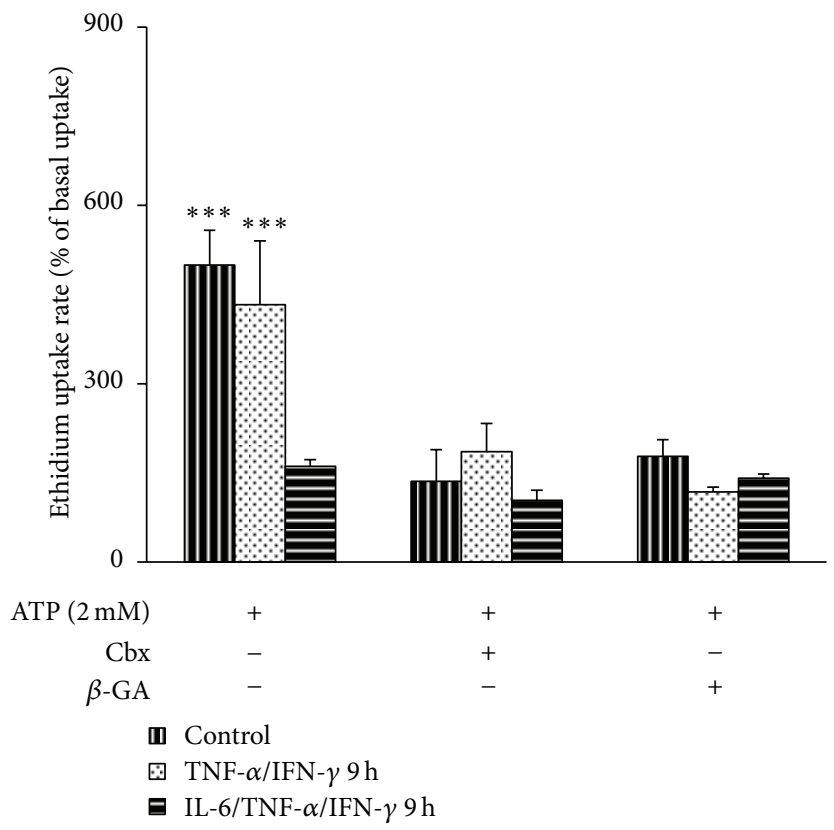

(b)

FIgURE 5: Extracellular ATP increases the cell membrane permeability in EOC20 cells. (a) Fluorescent views of Etd uptake of EOC20 cells cultured under control conditions before ( $0 \mathrm{~min}$ ) or after application of $2 \mathrm{mM} \mathrm{ATP} \mathrm{(5} \mathrm{and} 10 \mathrm{~min}$ ). Scale bar: $25 \mu \mathrm{m}$. Time-lapse measurement. After 5 min of basal uptake, $2 \mathrm{mM}$ ATP was added to extracellular solution. At 15 min of recording, $10 \mu \mathrm{M}$ of carbenoxolone (Cbx) a HC blocker was added to the bath. Black lines denote the slope at different times of Etd uptake. Data represent the mean \pm SEM of 30 cells in each of 5 independent experiments. (b) Graph showing the effect of acute application of extracellular ATP in EOC20 cells under control conditions or after treatment with TNF- $\alpha / \mathrm{IFN}-\gamma$ or with $50 \mathrm{ng} / \mathrm{mL}$ IL- 6 plus TNF- $\alpha / \mathrm{IFN}-\gamma$ for $9 \mathrm{~h}$. The effect of acute blockade with $10 \mu \mathrm{M}$ carbenoxolone (Cbx) or $50 \mu \mathrm{M} 18-\beta$-glycyrrhetinic acid $(\beta-\mathrm{GA})$ is also shown. Data was normalized to basal uptake in each condition (dashed line) and represents the mean \pm SEM. ${ }^{* * *} P<0.001$ versus control condition.

a Cx and Panx HC blocker (128 $\pm 47 \%$ of basal uptake, $n=5$; Figure 5). In cell cultures treated with TNF- $\alpha$ plus ATP for $3.5 \mathrm{~h}$, acute treatment with ATP did not induce a statistically significant increase in Etd uptake ( $173 \pm 17 \%$ of basal uptake, $n=5$, Figure S6a) and was blocked by Cbx $(85 \pm 16 \%$ of basal uptake, $n=5)$ or $\beta$-GA (102 $\pm 63 \%$ of basal uptake, $n=5$ Figure S6b). Similarly, cells treated with $10 \mathrm{ng} / \mathrm{mL}$ IL$6 /$ TNF- $\alpha$ plus ATP showed a small increase in Etd uptake rate after acute application of $2 \mathrm{mM}$ ATP $(196 \pm 28 \%$ of basal uptake, $n=5$, Figure S6b). This response was blocked by $\mathrm{Cbx}$ $(85 \pm 28 \%$ of basal uptake, $n=5)$ or $\beta$-GA $(102 \pm 63 \%$ of basal uptake, $n=5$; Figure S6b).

Moreover, EOC20 cells cultured for $9 \mathrm{~h}$ under control conditions showed a rapid increase of Etd uptake in response to $2 \mathrm{mM}$ ATP ( $500 \pm 58 \%$ of basal uptake, $n=5$ ), which was completely blocked by Cbx ( $136 \pm 53 \%$ of basal uptake, $n=5)$ or $\beta$-GA (178 $\pm 28 \%$ of basal uptake, $n=5$; Figure 5(b)). EOC20 cells treated with TNF- $\alpha /$ IFN- $\gamma$ for $9 \mathrm{~h}$ exhibited a significant increase in Etd uptake rate after ATP treatment ( $433 \pm 107 \%$ of basal uptake, $n=5$ ), which was blocked by Cbx ( $186 \pm 47 \%$ of basal uptake, $n=5)$ or $\beta$-GA (118 $\pm 8 \%$ of basal uptake, $n=5$ ). In contrast, in EOC20 cells treated for $9 \mathrm{~h}$ with $50 \mathrm{ng} / \mathrm{mL}$ IL- 6 plus TNF- $\alpha / \mathrm{IFN}-\gamma$, ATP did not increase Etd uptake ( $161 \pm 11 \%$ of basal uptake, $n=5)$, and neither $\mathrm{Cbx}(104 \pm 17 \%$ of basal uptake, $n=5)$ nor $\beta$-GA (141 $\pm 7 \%$ of basal uptake, $n=5$; Figure 5(b)) affected it.

In addition, cultures treated for $9 \mathrm{~h}$ with TNF- $\alpha / \mathrm{IL}-1 \beta$ showed increased Etd uptake rate after ATP application (510 \pm $58 \%$ of basal uptake, $n=5$, Figure S7a), which was partially blocked by Cbx (229 $\pm 32 \%$ of basal uptake, $n=5$, Figure S7a) or $\beta$-GA $(282 \pm 35 \%$ of basal uptake, $n=5)$. Interestingly, the ATP-induced increase in Etd uptake was almost completely absent in cells pretreated with $10 \mathrm{ng} / \mathrm{mL}$ IL- 6 plus TNF- $\alpha / \mathrm{IL}-$ $1 \beta(243 \pm 56 \%$ of basal uptake, $n=5$, Figure S7a) and the activity present was blocked by $10 \mu \mathrm{M} \mathrm{Cbx}(210 \pm 71 \%$ of basal uptake, $n=5)$ or $\beta$-GA (175 $\pm 49 \%$ of basal uptake, $n=5$; Figure S7a).

3.6. Blockade of Hemichannels Reduces the TNF- $\alpha / I F N-$ $\gamma$-Induced Dye Coupling. Open HCs allow the release of molecules such as ATP and glutamate $[35,56-58,64]$ and uptake of small molecules such as glucose [38]. In addition, in other cellular systems, functional Cx 46 HCs stimulate formation of GJCs [65]. Thus, we studied the possible contribution of increased HC activity on dye coupling induced by proinflammatory molecules in cells incubated with $\mathrm{HC}$ blockers. 


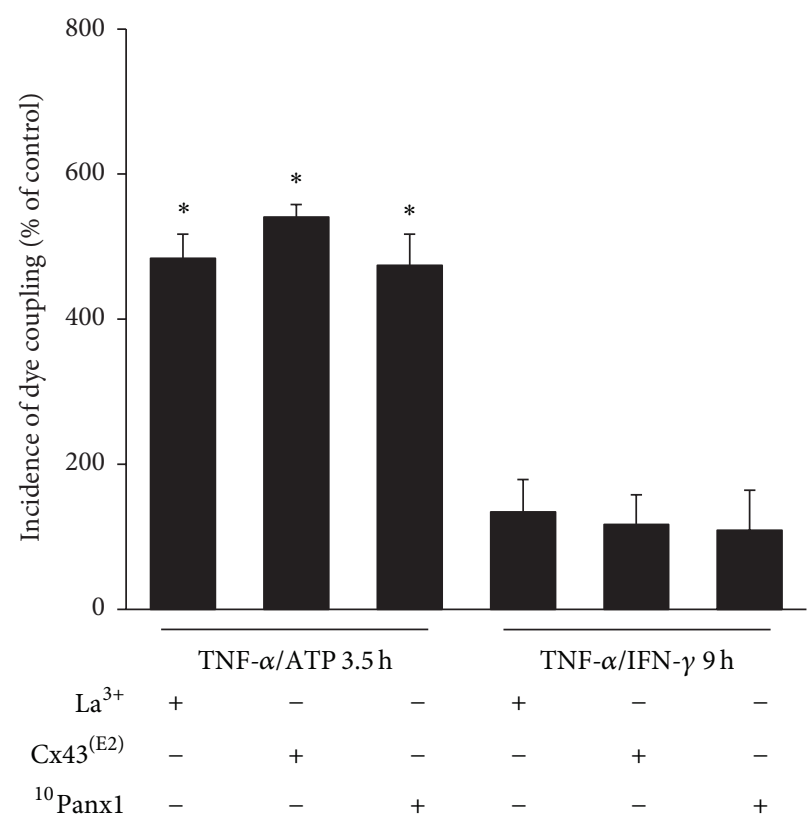

FIGURE 6: Blockade of HCs prevents upregulation of microglial gap junctional communication induced by TNF- $\alpha /$ IFN- $\gamma$, but not that induced by TNF- $\alpha$ plus ATP. Effect on the incidence of dye coupling (IDC) in EOC20 cells treated with TNF- $\alpha$ plus ATP for $3.5 \mathrm{~h}$ or TNF- $\alpha /$ IFN- $\gamma$ for $9 \mathrm{~h}$ in presence of $\mathrm{HC}$ blockers $\left(200 \mu \mathrm{M} \mathrm{La}^{3+}, 1: 500 \mathrm{Cx} 43^{(\mathrm{E} 2)}\right.$ antibody, $\left.200 \mu \mathrm{M}^{10} \mathrm{Panx1}\right)$. Data is expressed as percentage of IDC under control conditions (dashed line) and corresponds to the mean $\pm \mathrm{SEM}, n=4 .{ }^{*} P<0.05$ versus control condition.

Treatment with $200 \mu \mathrm{M} \mathrm{La}^{3+}$ prevented the TNF- $\alpha / \mathrm{IFN}-\gamma$ induced dye coupling recorded as IDC ( $134 \pm 45 \%$ of control, $n=4$; Figure 6). A similar inhibitory effect was induced by the application of $1: 500 \mathrm{Cx} 43^{(\mathrm{E} 2)}$ antibody $(117 \pm 41 \%$ of control, $n=4$ ), a specific Cx43 HC blocker [66], or $200 \mu \mathrm{M}$ ${ }^{10}$ Panx1 (IDC in EOC20 cells: $109 \pm 55 \%$ of control, $n=$ 4; Figure 6). However, neither irrelevant IgG nor scramble ${ }^{10}$ Panxl peptide prevented the TNF- $\alpha / \mathrm{IFN}-\gamma$-induced dye coupling (data not shown). On the other hand, treatment with $\mathrm{La}^{3+}(484 \pm 34 \%$ of control, $n=4), \mathrm{Cx} 43^{(\mathrm{E} 2)}$ antibody $(540.8 \pm 30 \%$ of control, $n=4)$ or ${ }^{10} \mathrm{Panxl}(474 \pm 43 \%$ of control, $n=4$ ) did not change the dye coupling induced by TNF- $\alpha$ plus ATP (Figure 6).

3.7. Pro-Inflammatory Molecules Regulate Cx43 and Panx1 Levels and Distribution in Microglia. Cx32, Cx36, and Cx43 have been detected in cultured microglia [23, 24, 26-28]. However, Cx43 seems to be the main contributor involved in cytokine-induced gap junctional communication, because microglia from $\mathrm{Cx} 43^{\mathrm{del} / \mathrm{del}}$ mice do not express functional GJCs in response to TNF- $\alpha / \mathrm{IFN}-\gamma$ [23]. In addition, expression of Panxl by microglia has been reported recently [35]. Thus, the distribution and levels of Cx43 and Panxl during treatments that affect GJC and HC activity were evaluated by immunofluorescence and Western blot analyses.

Under control conditions, rat microglia presented low and heterogeneous Cx43 and Panxl reactivity (Figure 7(a)). After treatment with TNF- $\alpha$ plus ATP $(3.5 \mathrm{~h})$ or TNF- $\alpha /$ IFN$\gamma$ (9h) Cx43 and Panxl reactivity were higher than in control conditions (Figure $7(\mathrm{a})$ ). However, treatment with
IL-6 (10 ng/mL)/TNF- $\alpha$ plus ATP or IL-6 (50 ng/mL)/TNF$\alpha /$ IFN $-\gamma$ did not affect the reactivity of Cx43 and Panxl (Figure 7(a)). Moreover, in cultures treated with IL-6 plus TNF- $\alpha$ /ATP a redistribution of $\mathrm{Cx} 43$ and Panxl was observed; these proteins were segregated providing a "cell polarization" appearance, which was quantified (Figure 7(b)). Under control conditions rat microglia exhibited little or no segregation (polarized: $19 \pm 6 \%, n=5$ ) although some cells showed more Cx43 or Panxl reactivity. Segregation of these proteins was not significantly affected by TNF- $\alpha$ plus ATP for $3.5 \mathrm{~h}$ (polarized: $8 \pm 4 \%, n=5$ ), but the number of cells with segregation was increased by the simultaneous treatment with IL- 6 and TNF- $\alpha$ plus ATP (polarized: $61 \pm 1 \%$, $n=5)$. However, treatment with TNF- $\alpha /$ IFN- $\gamma$ for $9 \mathrm{~h}$ did not affect the resting distribution (polarized: $21 \pm 6 \%, n=5$ ) and remained unchanged in cells simultaneously treated with IL6/TNF- $\alpha / \mathrm{IFN}-\gamma$ (polarized: $15 \pm 4 \%, n=5$ ). Similar results were found in EOC2 0 cells treated with TNF- $\alpha / \mathrm{IL}-1 \beta$ for $9 \mathrm{~h}$ (Figure S7b).

Protein levels were evaluated in EOC20 cells by Western blot analyses. Total levels of $\mathrm{Cx} 43$ and Panx1 increased after treatments with TNF- $\alpha$ plus ATP, TNF- $\alpha / \mathrm{IFN}-\gamma$ or TNF$\alpha /$ IL- $1 \beta$, which caused the maximal effect on gap junctional communication (Figure 7(c)). Only the increase in total Cx43 levels was prevented by IL- 6 in the same conditions that prevented the induction of dye coupling. Even when IL-6 prevented the increase in total Panxl levels after treatment with TNF- $\alpha /$ IFN- $\gamma$, or TNF- $\alpha /$ IL- $1 \beta$, coapplication of IL- 6 failed to prevent the increase observed after TNF- $\alpha$ plus ATP treatment (Figure 7(c)). 

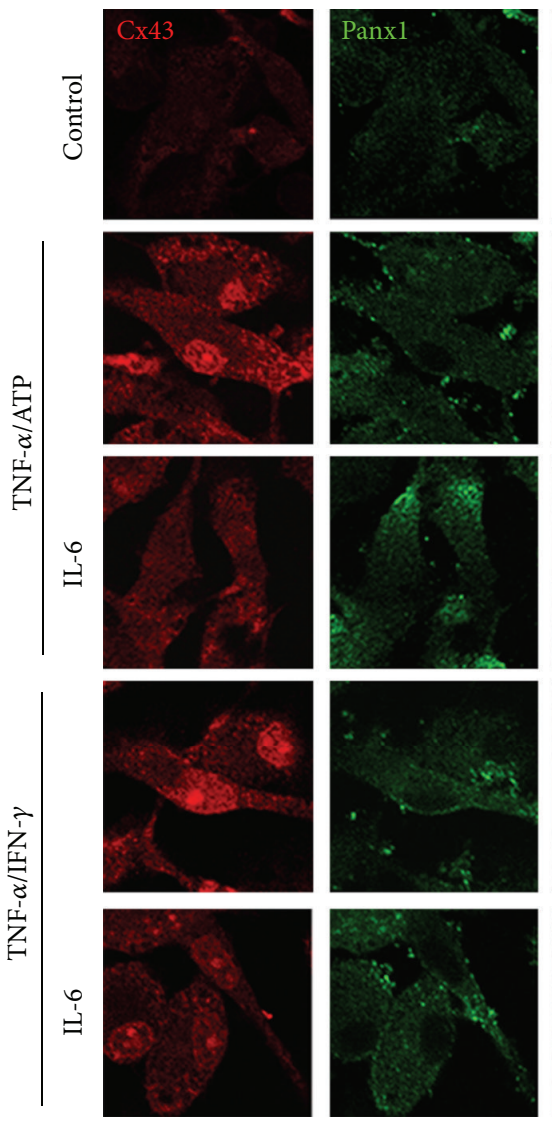

(a)
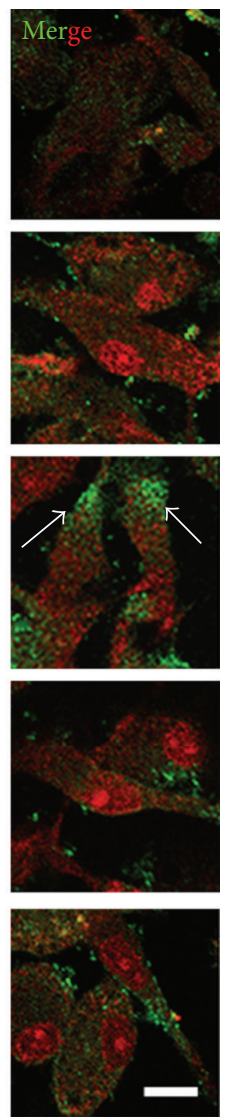

(2)

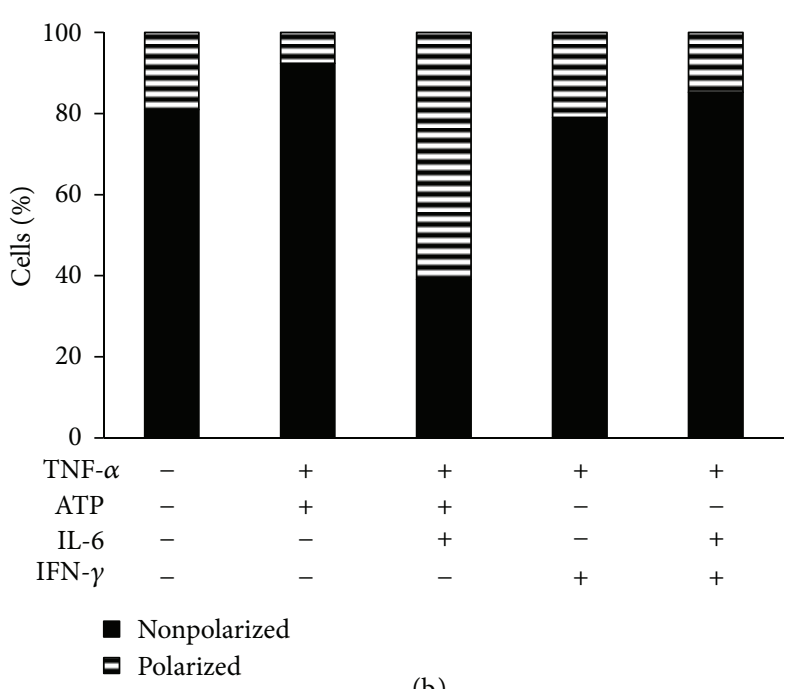

(b)
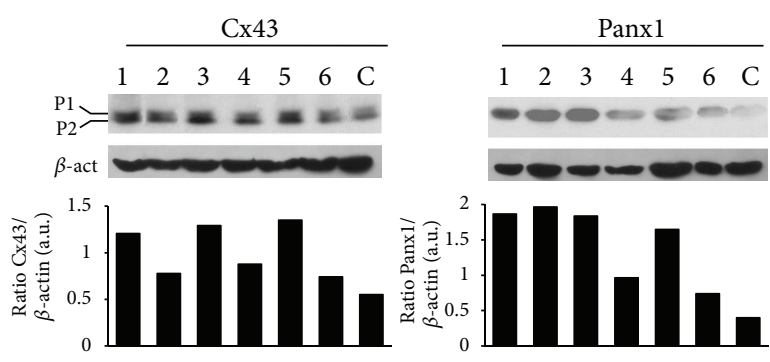

(c)

FIgure 7: Pro-inflammatory treatments upregulate Cx43 and Panxl protein levels in microglia. (a) Confocal images show immunoreactivity for $\mathrm{Cx} 43$ (red) and Panxl (green) in primary rat microglia under control conditions of after treatment with TNF- $\alpha$ plus ATP for $3.5 \mathrm{~h}$ or with TNF- $\alpha / \mathrm{IFN}-\gamma$ for $9 \mathrm{~h}$, in absence or presence of IL-6 (10 or $50 \mathrm{ng} / \mathrm{mL}$, respectively). Arrows show microglia with segregation of Cx 43 and Panxl. Scale bar: $10 \mu \mathrm{m}$. (b) Quantification of nonpolarized (black bars) versus polarized (dashed white bars) rat microglia under control conditions or after treatments shown in (a). Data are expressed as a percentage of the total number of cells per field, $n=5$ (up to 100 cells per field). ${ }^{*} P<0.05$ versus control condition. (c) Representative Western blots from 3 independent experiments showing total protein levels of Cx43 and Panxl. Cell lysates were obtained from EOC20 cells under control conditions (lane C) or after the following treatments: TNF- $\alpha$ plus ATP (lane 1), IL-6/TNF- $\alpha$ plus ATP (lane 2), TNF- $\alpha /$ IFN- $\gamma$ (lane 3), IL-6/TNF- $\alpha /$ IFN- $\gamma$ (lane 4 ), TNF- $\alpha /$ IL-1 $\beta$ (lane 5), and IL-6/TNF- $\alpha /$ IL-1 $\beta$ (lane 6). Quantitation of Cx43 and Panx1 is shown; $\beta$-actin was used as a loading control for densitometric analysis.

\section{Discussion}

In this study, we demonstrated that extracellular ATP is required and advances the TNF- $\alpha / \mathrm{IFN}-\gamma$-induced dye coupling in cultured microglia, in an IL- $1 \beta$-dependent manner. TNF- $\alpha /$ IFN- $\gamma$, but not TNF- $\alpha$ plus ATP enhances the basal and ATP-induced membrane permeability mediated by HCs. The increase in dye coupling induced by TNF- $\alpha / \mathrm{IFN}-\gamma$ or TNF- $\alpha$ plus ATP was blocked by IL-6. Furthermore, inhibition of HCs prevents the pro-inflammatory moleculesinduced upregulation of GJCs.

The ATP effects on the TNF- $\alpha /$ IFN- $\gamma$-induced dye coupling could be explained by activation of $\mathrm{P} 2 \mathrm{X}$ receptors via ATP release, because the TNF- $\alpha /$ IFN- $\gamma$-induced dye coupling was prevented by oATP, a $\mathrm{P} 2 \mathrm{X}$ receptor blocker. Activation of $\mathrm{P} 2 \mathrm{X}$ receptors in microglia rises the $\left[\mathrm{Ca}^{2+}\right]_{i}[1]$, which is known to induce gap junctional communication between cultured microglia in a PKC-dependent manner [24]. In agreement with the latter, BAPTA loaded microglia did not present dye coupling after treatment with TNF- $\alpha$ plus ATP. Thus, it is suggested that rises in $\left[\mathrm{Ca}^{2+}\right]_{i}$ together with other downstream pathways contribute to up-regulate $\mathrm{Cx} 43$ levels and formation of HCs and GJCs as observed in other cell types $[45,67]$. In HeLa cells expressing Cx43, rises in $\left[\mathrm{Ca}^{2+}\right]_{i}$ enhance the cell surface levels of Cx43 HCs [45], a response that is directly associated to ATP release [68]. Thus, rises in $\left[\mathrm{Ca}^{2+}\right]_{i}$ might contribute to increase the number of $\mathrm{HCs}$ in the plasma membrane of microglia. The increase in $\left[\mathrm{Ca}^{2+}\right]_{i}$ could be initially mediated by activation of $\mathrm{P} 2 \mathrm{X}$ receptors, but later on HCs might also contribute to increase their own activity favoring the $\mathrm{Ca}^{2+}$ influx because they are permeable to $\mathrm{Ca}^{2+}$ [69-71]. 


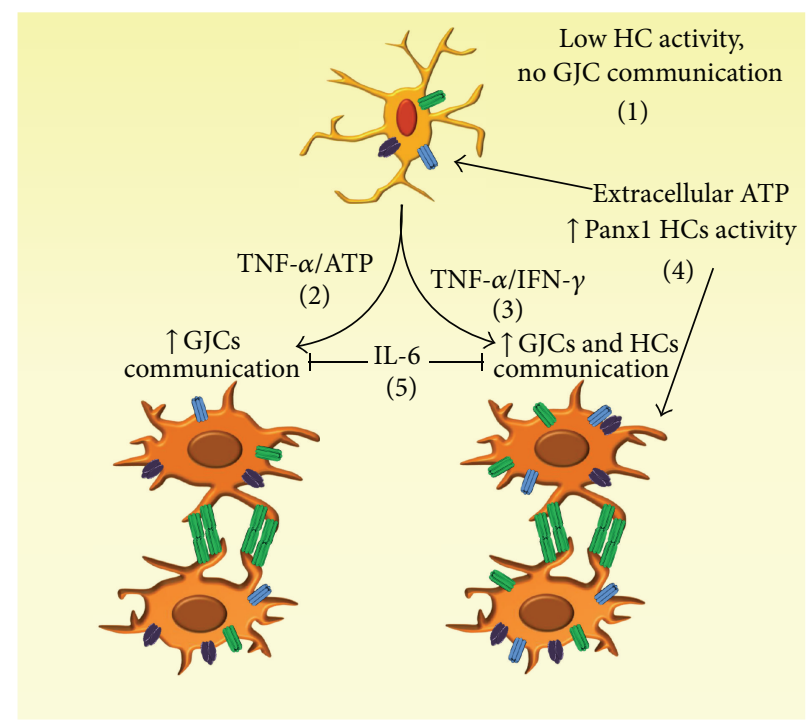

$\begin{array}{ll}\text { P2X receptor } & \text { Cx GJC } \\ \text { Cx HC } & \text { If Panxi HC }\end{array}$

FIGURE 8: Cytokine-induced activation and the effect on gap junctional communication and HCs activity in cultured microglia. (1) Under resting condition, microglia express $\mathrm{P} 2 \mathrm{X}$ receptors, $\mathrm{Cx} 43$, and Panxl, which have a low activity. Furthermore, no gap junction channel (GJC) communication is observed. (2) After TNF- $\alpha$ plus ATP exposition activated microglia exhibit gap junctional communication, but not intercellular communication mediated by hemichannels (HCs). (3) However, treatment with TNF- $\alpha /$ IFN- $\gamma$ increased both GJC and HC functional state. (4) Extracellular ATP increases the Panx1 HC activity in both, resting or TNF- $\alpha /$ IFN- $\gamma$-activated microglia. (5) IL-1 $\beta$ release from activated microglia favors gap junctional communication. (6) IL-6 prevents IL-1 $\beta$ release and the increase in GJC and HC functional state.

The cytokine-dependent induction of gap junctional communication between microglial cells was transient, as previously observed in dendritic cells and monocytes/macrophages $[50,51,72]$. The transient response might be explained by the production and release of anti-inflammatory cytokines, such as IL-6, IL-10, and TGF- $\beta$, by activated microglia [1]. Accordingly, IL-6 drastically reduces the cytokine-induced dye coupling between microglia treated with TNF- $\alpha$ plus ATP or TNF- $\alpha /$ IFN- $\gamma$ as it also occurs in dendritic cells treated with TNF- $\alpha /$ IL- $1 \beta$ [50]. Since IL-6 reduces cell adhesion in breast cancer cells [73], a similar mechanism might affect the stability of cellular contacts between microglia, impairing gap junctional communication. In addition, IL- 6 was found to prevent the rise in $\left[\mathrm{Ca}^{2+}\right]_{i}$. This might explain the inhibition of TNF$\alpha$ plus ATP, because IL- 6 did not prevent the increase in Panxl levels. Although, IFN- $\gamma$ signaling positively regulates purinergic receptors in microglia [11, 74], this might not explain the increase in dye coupling induced by TNF- $\alpha /$ IFN$\gamma$ because we found that IFN- $\gamma$ delayed the appearance of dye coupling induced by TNF- $\alpha$ plus ATP. Further studies are required to unveil the mechanism underlying this cellular response.

We also found that in addition to TNF- $\alpha /$ IFN- $\gamma$, extracellular ATP and IL-1 $\beta$ also positively modulate the formation of
GJCs in microglia. The link between purinergic signaling and IL-1 $\beta$ release has been well established in microglia [75], and here it was corroborated in EOC20 cells using IL-1ra, which prevented IL-1 $\beta$ release and establishment of dye coupling upon treatment with TNF- $\alpha$ plus ATP or TNF- $\alpha /$ IFN- $\gamma$. Interestingly, pro-inflammatory-like conditions (TNF- $\alpha / \mathrm{IL}-$ $1 \beta$ or supernatant of microglia pretreated with LPS) increase HC activity but decrease gap junctional communication in primary astrocytes cultures [38]. However, we observed that TNF- $\alpha / \mathrm{IFN}-\gamma$ increases both $\mathrm{HC}$ and GJC activity in microglia, indicating that different mechanisms control the functional expression of these channels in astrocytes and microglia.

As shown in this work, the activity of microglial $\mathrm{Cx}$ and Panx HCs was increased by TNF- $\alpha / \mathrm{IFN}-\gamma$. Interestingly, Panxl HCs and several Cx HCs are pathways of ATP release to the extracellular space in several cell types including astrocytes and microglia $[25,35,37,76,77]$. Therefore, enhanced HC opening may control ATP release from activated microglia maintaining a higher $\left[\mathrm{Ca}^{2+}\right]_{i}$ compared with resting microglia [78]. Extracellular ATP could open Panx1 $\mathrm{HCs}$, which are also activated after TNF- $\alpha / \mathrm{IFN}-\gamma$, leading to release of IL-1 $\beta$ [31]. Because, the $\mathrm{HC}$ activity remains low after treatment with TNF- $\alpha$ plus ATP, even after acute application of ATP, we propose that under these conditions 
ATP released by microglia via HCs was not required to induce IL- $1 \beta$ release. The latter is consistent with the prevention of TNF- $\alpha / \mathrm{IFN}-\gamma$-, but not TNF- $\alpha$ plus ATP-induced dye coupling in EOC20 cells treated with ${ }^{10}$ Panxl, a Panxl HC blocker. In addition, we speculate that after treatment with TNF- $\alpha$ plus ATP P2X receptors also contribute in a Panxl HC-independent way, as it has been proposed to occur during microglial proliferation [79]. The role of $\mathrm{Cx} 43 \mathrm{HCs}$ in TNF- $\alpha /$ IFN- $\gamma$-induced dye coupling was confirmed using $\mathrm{Cx} 43^{(\mathrm{E} 2)}$ antibody, a specific $\mathrm{Cx} 43$ HC blocker. However, this conclusion should be taken cautiously because it was recently shown that several hours after $\mathrm{Cx} 43^{(\mathrm{E} 2)}$ antibody application, gap junctional communication is partially reduced [42].

Under control conditions microglial cells express low levels of Cxs [23, 24, 26-28]. Accordingly, in this study we detected low levels of $\mathrm{Cx} 43$ and also Panx1. However, brain damage or cytokine exposure promotes microglial activation, and under this condition they present elevated levels of $\mathrm{Cx} 43$ and become coupled through GJCs [23, 24, 27, 28]. Here we found that TNF- $\alpha$ in presence of IFN $-\gamma$ upregulates $\mathrm{Cx} 43$ GJCs in microglia as it was previously demonstrated $[23,28]$. In addition, and similar to dendritic cells [50], TNF- $\alpha /$ IL- $1 \beta$ increased Cx43 levels in microglia. On the other hand, IL-6 prevents the formation of GJCs induced by pro-inflammatory cytokines in dendritic cells [50]. Accordingly, we found that IL-6 efficiently prevented the pro-inflammatory moleculesinduced increase in GJC and HC activity in microglia. This effect could be explained, at least in part, by prevention of Cx43 and Panxl upregulation by IL- 6 and prevention of IL-1 $\beta$ release.

So far, Panxl has been demonstrated to form GJCs only in exogenous expression systems [71]. Together with the evidence that microglia from $\mathrm{Cx} 43^{\mathrm{del} / \mathrm{del}}$ mice do not express functional GJCs [23] and that $\mathrm{Cx} 43^{(\mathrm{E} 2)}$ antibody prevented the pro-inflammatory-induced dye coupling, it is suggested that dye coupling induced by TNF- $\alpha$ plus ATP or TNF$\alpha /$ IFN- $\gamma$ could be due to $\mathrm{Cx} 43$ GJCs. To recapitulate, we propose that in presence of extracellular ATP, Panxl HC activity is enhanced and microglia migrate toward the injured site and release cytokines, as reported previously [33]. ATP could act in an autocrine and paracrine manner allowing IL$1 \beta$ release and providing a pro-inflammatory microenvironment, which promotes an early up-regulation of $\mathrm{Cx} 43$ and Panxl, favoring the formation of HCs and GJCs in a stimulusdependent manner (Figure 8). Later on, anti-inflammatory cytokines are produced and released to the extracellular milieu leading to reduction in intercellular communication mediated by $\mathrm{HCs}$ and GJCs similar to that of resting conditions. The latter is relevant because downregulation prevents a massive and/or prolonged ATP/glutamate release from microglia, which in turn can induce neurodegeneration $[35,56]$. Thus, understanding the regulation of microglial purinergic receptors and intercellular communication via HCs and GJCs might contribute to modulate the timing of neuroinflammatory responses and led us to the identification of new therapeutic targets for neurodegenerative diseases [80].

\section{Acknowledgments}

This work was partially supported by Grants CONICYT 24100062 (to P. J. Sáez); FONDECYT 1111033, FONDEF DO7I1086 and ANILLO ACT-71 (to J. C. Sáez); FONDECYT 1090353 (R. von Bernhardi); Welch Foundation Grant, AQ1507 (to J. X. Jiang). All the authors declare no conflict of interests. The data of this work was presented by Pablo J. Sáez as partial fulfillment of the requirements to obtain the degree of Bachelor of Sciences in Biology at the Pontificia Universidad Católica de Chile.

\section{References}

[1] H. Kettenmann, U. K. Hanisch, M. Noda, and A. Verkhratsky, "Physiology of microglia," Physiological Reviews, vol. 91, pp. 461-553, 2011.

[2] R. M. Ransohoff and V. H. Perry, "Microglial physiology: unique stimuli, specialized responses," Annual Review of Immunology, vol. 27, pp. 119-145, 2009.

[3] K. Inoue, "Purinergic systems in microglia," Cellular and Molecular Life Sciences, vol. 65, no. 19, pp. 3074-3080, 2008.

[4] R. Von Bernhardi, J. E. Tichauer, and J. Eugenín, “Agingdependent changes of microglial cells and their relevance for neurodegenerative disorders," Journal of Neurochemistry, vol. 112, no. 5, pp. 1099-1114, 2010.

[5] S. W. Barger and A. S. Basile, "Activation of microglia by secreted amyloid precursor protein evokes release of glutamate by cystine exchange and attenuates synaptic function," Journal of Neurochemistry, vol. 76, no. 3, pp. 846-854, 2001.

[6] R. De Simone, G. Levi, and F. Aloisi, "Interferon $\gamma$ gene expression in rat central nervous system glial cells," Cytokine, vol. 10, no. 6, pp. 418-422, 1998.

[7] U. K. Hanisch, "Microglia as a source and target of cytokines," Glia, vol. 40, no. 2, pp. 140-155, 2002.

[8] Y. K. Soo, H. M. Ju, G. L. Hwan, U. K. Seung, and B. L. Yong, "ATP released from $\beta$-amyloid-stimulated microglia induces reactive oxygen species production in an autocrine fashion," Experimental and Molecular Medicine, vol. 39, no. 6, pp. 820827, 2007.

[9] D. Piani and A. Fontana, "Involvement of the cystine transport system xc/- in the macrophage-induced glutamate-dependent cytotoxicity to neurons," Journal of Immunology, vol. 152, no. 7, pp. 3578-3585, 1994.

[10] C. C. Chao, S. Hu, L. Ehrlich, and P. K. Peterson, "Interleukin-1 and tumor necrosis factor- $\alpha$ synergistically mediate neurotoxicity: involvement of nitric oxide and of N-methyl-D-aspartate receptors," Brain, Behavior, and Immunity, vol. 9, no. 4, pp. 355365,1995

[11] F. P. Gendron, M. Chalimoniuk, J. Strosznajder et al., "P2X7 nucleotide receptor activation enhances IFN $\gamma$-induced type II nitric oxide synthase activity in BV-2 microglial cells," Journal of Neurochemistry, vol. 87, no. 2, pp. 344-352, 2003.

[12] R. Kuno, J. Wang, J. Kawanokuchi, H. Takeuchi, T. Mizuno, and A. Suzumura, "Autocrine activation of microglia by tumor necrosis factor- $\alpha$," Journal of Neuroimmunology, vol. 162, no. 1-2, pp. 89-96, 2005.

[13] K. Inoue, "Microglial activation by purines and pyrimidines," Glia, vol. 40, no. 2, pp. 156-163, 2002. 
[14] F. Bianco, E. Pravettoni, A. Colombo et al., "Astrocyte-derived ATP induces vesicle shedding and IL- $1 \beta$ release from microglia," Journal of Immunology, vol. 174, no. 11, pp. 7268-7277, 2005.

[15] C. G. Schipke, C. Boucsein, C. Ohlemeyer, F. Kirchhoff, and H. Kettenmann, "Astrocyte $\mathrm{Ca}^{2+}$ waves trigger responses in microglial cells in brain slices," The FASEB Journal, vol. 16, no. 2, pp. 255-257, 2002.

[16] C. Verderio and M. Matteoli, "ATP mediates calcium signaling between astrocytes and microglial cells: modulation by IFN- $\gamma$," Journal of Immunology, vol. 166, no. 10, pp. 6383-6391, 2001.

[17] J. M. Sanz, P. Chiozzi, D. Ferrari et al., "Activation of microglia by amyloid $\beta$ requires $\mathrm{P}_{2} \mathrm{X}_{7}$ receptor expression," Journal of Immunology, vol. 182, no. 7, pp. 4378-4385, 2009.

[18] S. D. Skaper, P. Debetto, and P. Giusti, "The $\mathrm{P}_{2} \mathrm{X}_{7}$ purinergic receptor: from physiology to neurological disorders," FASEB Journal, vol. 24, no. 2, pp. 337-345, 2010.

[19] D. Ferrari, P. Chiozzi, S. Falzoni, S. Hanau, and F. Di Virgilio, "Purinergic modulation of interleukin- $1 \beta$ release from microglial cells stimulated with bacterial endotoxin," Journal of Experimental Medicine, vol. 185, no. 3, pp. 579-582, 1997.

[20] D. R. Seo, K. Y. Kim, and Y. B. Lee, "Interleukin-10 expression in lipopolysaccharide-activated microglia is mediated by extracellular ATP in an autocrine fashion," NeuroReport, vol. 15, no. 7, pp. 1157-1161, 2004.

[21] K. Färber and H. Kettenmann, "Functional role of calcium signals for microglial function," Glia, vol. 54, no. 7, pp. 656-665, 2006.

[22] A. Hoffmann, O. Kann, C. Ohlemeyer, U. K. Hanisch, and H. Kettenmann, "Elevation of basal intracellular calcium as a central element in the activation of brain macrophages (microglia): suppression of receptor-evoked calcium signaling and control of release function," Journal of Neuroscience, vol. 23, no. 11, pp. 4410-4419, 2003.

[23] E. A. Eugenín, D. Eckardt, M. Theis, K. Willecke, M. V. L. Bennett, and J. C. Sáez, "Microglia at brain stab wounds express connexin 43 and in vitro form functional gap junctions after treatment with interferon- $\gamma$ and tumor necrosis factor- $\alpha$," Proceedings of the National Academy of Sciences of the United States of America, vol. 98, no. 7, pp. 4190-4195, 2001.

[24] A. D. Martínez, E. A. Eugenín, M. C. Brañes, M. V. Bennett, and J. C. Sáez, "Identification of second messengers that induce expression of functional gap junctions in microglia cultured from newborn rats," Brain Research, vol. 943, pp. 191-201, 2002.

[25] J. A. Orellana, P. J. Sáez, K. F. Shoji et al., "Modulation of brain hemichannels and gap junction channels by pro-inflammatory agents and their possible role in neurodegeneration," Antioxidants and Redox Signaling, vol. 11, no. 2, pp. 369-399, 2009.

[26] K. Dobrenis, H. Y. Chang, M. H. Pina-Benabou et al., "Human and mouse microglia express connexin36, and functional gap junctions are formed between rodent microglia and neurons," Journal of Neuroscience Research, vol. 82, no. 3, pp. 306-315, 2005.

[27] S. Garg, M. M. Syed, and T. Kielian, "Staphylococcus aureusderived peptidoglycan induces Cx43 expression and functional gap junction intercellular communication in microglia," Journal of Neurochemistry, vol. 95, no. 2, pp. 475-483, 2005.

[28] S. B. Shaikh, B. Uy, A. Perera, and L. F. Nicholson, "AGEs-RAGE mediated up-regulation of connexin 43 in activated human microglial CHME-5 cells," Neurochemistry International, vol. 60, no. 6, pp. 640-651, 2012.
[29] Y. V. Panchin, "Evolution of gap junction proteins-the pannexin alternative," Journal of Experimental Biology, vol. 208, no. 8, pp. 1415-1419, 2005.

[30] S. Locovei, J. Wang, and G. Dahl, "Activation of pannexin 1 channels by ATP through P2Y receptors and by cytoplasmic calcium," FEBS Letters, vol. 580, no. 1, pp. 239-244, 2006.

[31] P. Pelegrin and A. Surprenant, "Pannexin-1 mediates large pore formation and interleukin- $1 \beta$ release by the ATP-gated $\mathrm{P}_{2} \mathrm{X}_{7}$ receptor," EMBO Journal, vol. 25, no. 21, pp. 5071-5082, 2006.

[32] L. Bao, S. Locovei, and G. Dahl, "Pannexin membrane channels are mechanosensitive conduits for ATP," FEBS Letters, vol. 572, no. 1-3, pp. 65-68, 2004.

[33] D. Davalos, J. Grutzendler, G. Yang et al., "ATP mediates rapid microglial response to local brain injury in vivo," Nature Neuroscience, vol. 8, no. 6, pp. 752-758, 2005.

[34] A. M. Fontainhas, M. Wang, K. J. Liang et al., "Microglial morphology and dynamic behavior is regulated by ionotropic glutamatergic and GABAergic neurotransmission," PLoS ONE, vol. 6, no. 1, article e15973, 2011.

[35] J. A. Orellana, K. F. Shoji, V. Abudara et al., "Amyloid $\beta$-induced death in neurons involves glial and neuronal hemichannels," Journal of Neuroscience, vol. 31, no. 13, pp. 4962-4977, 2011.

[36] N. Froger, J. A. Orellana, C. F. Calvo et al., "Inhibition of cytokine-induced connexin43 hemichannel activity in astrocytes is neuroprotective," Molecular and Cellular Neuroscience, vol. 45, no. 1, pp. 37-46, 2010.

[37] J. A. Orellana, N. Froger, P. Ezan et al., "ATP and glutamate released via astroglial connexin 43 hemichannels mediate neuronal death through activation of pannexin 1 hemichannels," Journal of Neurochemistry, vol. 118, pp. 826-840, 2011.

[38] M. A. Retamal, N. Froger, N. Palacios-Prado et al., " $\mathrm{Cx} 43$ hemichannels and gap junction channels in astrocytes are regulated oppositely by proinflammatory cytokines released from activated microglia," Journal of Neuroscience, vol. 27, no. 50, pp. 13781-13792, 2007.

[39] S. Buvinic, G. Almarza, M. Bustamante et al., "ATP released by electrical stimuli elicits calcium transients and gene expression in skeletal muscle," Journal of Biological Chemistry, vol. 284, no. 50, pp. 34490-34505, 2009.

[40] L. A. Cea, M. A. Riquelme, B. A. Cisterna et al., "Connexin- and pannexin-based channels in normal skeletal muscles and their possible role in muscle atrophy," Journal of Membrane Biology, vol. 245, pp. 423-436, 2012.

[41] M. C. Brañes, J. E. Contreras, and J. C. Sáez, "Activation of human polymorphonuclear cells induces formation of functional gap junctions and expression of connexins," Medical Science Monitor, vol. 8, pp. BR313-BR323, 2002.

[42] B. Bao, J. Jiang, T. Yanase, Y. Nishi, and J. R. Morgan, "Connexon-mediated cell adhesion drives microtissue selfassembly," FASEB Journal, vol. 25, no. 1, pp. 255-264, 2011.

[43] W. S. Walker, J. Gatewood, E. Olivas, D. Askew, and C. E. G. Havenith, "Mouse microglial cell lines differing in constitutive and interferon- $\gamma$-inducible antigen-presenting activities for naive and memory $\mathrm{CD}^{+}$and $\mathrm{CD}^{+} \mathrm{T}$ cells," Journal of Neuroimmunology, vol. 63, no. 2, pp. 163-174, 1995.

[44] M. D. Sklar, A. Tereba, B. D. M. Chen, and W. S. Walker, "Transformation of mouse bone marrow cells by transfection with a human oncogene related to c-myc is associated with the endogenous production of macrophage colony stimulating factor 1," Journal of Cellular Physiology, vol. 125, no. 3, pp. 403$412,1985$. 
[45] K. A. Schalper, N. Palacios-Prado, M. A. Retamal, K. F. Shoji, A. D. Martínez, and J. C. Sáez, "Connexin hemichannel composition determines the FGF-1-induced membrane permeability and free $\left[\mathrm{Ca}^{2+}\right]_{i}$ responses," Molecular Biology of the Cell, vol. 19, no. 8, pp. 3501-3513, 2008.

[46] T. Nagano, Y. Kawasaki, A. Baba, M. Takemura, and T. Matsuda, "Up-regulation of $\mathrm{Na}^{+}-\mathrm{Ca}^{2+}$ exchange activity by interferon- $\gamma$ in cultured rat microglia," Journal of Neurochemistry, vol. 90, no. 4, pp. 784-791, 2004.

[47] S. Franciosi, H. B. Choi, S. U. Kim, and J. G. McLarnon, "Interferon- $\gamma$ acutely induces calcium influx in human microglia," Journal of Neuroscience Research, vol. 69, no. 5, pp. 607-613, 2002.

[48] T. Möller, "Calcium signaling in microglial cells," Glia, vol. 40, no. 2, pp. 184-194, 2002.

[49] J. G. McLarnon, S. Franciosi, X. Wang, J. H. Bae, H. B. Choi, and S. U. Kim, "Acute actions of tumor necrosis factor- $\alpha$ on intracellular $\mathrm{Ca}^{2+}$ and $\mathrm{K}^{+}$currents in human microglia," Neuroscience, vol. 104, no. 4, pp. 1175-1184, 2001.

[50] L. A. Corvalán, R. Araya, M. C. Brañes et al., "Injury of skeletal muscle and specific cytokines induce the expression of gap junction channels in mouse dendritic cells," Journal of Cellular Physiology, vol. 211, pp. 649-660, 2007.

[51] E. A. Eugenín, M. C. Brañes, J. W. Berman, and J. C. Sáez, "TNF$\alpha$ plus IFN- $\gamma$ induce connexin 43 expression and formation of gap junctions between human monocytes/macrophages that enhance physiological responses," Journal of Immunology, vol. 170, no. 3, pp. 1320-1328, 2003.

[52] Y. Shigemoto-Mogami, S. Koizumi, M. Tsuda, K. Ohsawa, S. Kohsaka, and K. Inoue, "Mechanisms underlying extracellular ATP-evoked interleukin-6 release in mouse microglial cell line, MG-5," Journal of Neurochemistry, vol. 78, no. 6, pp. 1339-1349, 2001.

[53] R. A. North, "Molecular physiology of P2X receptors," Physiological Reviews, vol. 82, no. 4, pp. 1013-1067, 2002.

[54] J. G. McLarnon, "Purinergic mediated changes in $\mathrm{Ca}^{2+}$ mobilization and functional responses in microglia: effects of low levels of ATP," Journal of Neuroscience Research, vol. 81, no. 3, pp. 349-356, 2005.

[55] F. Pousset, K. Palin, D. Verrier et al., "Production of interleukin1 receptor antagonist isoforms by microglia in mixed rat glial cells stimulated by lipopolysaccharide," European Cytokine Network, vol. 11, no. 4, pp. 682-689, 2000.

[56] H. Takeuchi, S. Jin, J. Wang et al., "Tumor necrosis factor- $\alpha$ induces neurotoxicity via glutamate release from hemichannels of activated microglia in an autocrine manner," Journal of Biological Chemistry, vol. 281, no. 30, pp. 21362-21368, 2006.

[57] H. Takeuchi, H. Mizoguchi, Y. Doi et al., "Blockade of gap junction hemichannel suppresses disease progression in mouse models of amyotrophic lateral sclerosis and Alzheimer's disease," PLoS ONE, vol. 6, no. 6, article e21108, 2011.

[58] I. Yawata, H. Takeuchi, Y. Doi, J. Liang, T. Mizuno, and A. Suzumura, "Macrophage-induced neurotoxicity is mediated by glutamate and attenuated by glutaminase inhibitors and gap junction inhibitors," Life Sciences, vol. 82, no. 21-22, pp. 1111-1116, 2008.

[59] J. E. Contreras, H. A. Sánchez, E. A. Eugenin et al., "Metabolic inhibition induces opening of unapposed connexin 43 gap junction hemichannels and reduces gap junctional communication in cortical astrocytes in culture," Proceedings of the National Academy of Sciences of the United States of America, vol. 99, no. 1, pp. 495-500, 2002.
[60] R. Bruzzone, M. T. Barbe, N. J. Jakob, and H. Monyer, "Pharmacological properties of homomeric and heteromeric pannexin hemichannels expressed in Xenopus oocytes," Journal of Neurochemistry, vol. 92, no. 5, pp. 1033-1043, 2005.

[61] D. Ferrari, M. Villalba, P. Chiozzi, S. Falzoni, P. RicciardiCastagnoli, and F. Di Virgilio, "Mouse microglial cells express a plasma membrane pore gated by extracellular ATP," Journal of Immunology, vol. 156, no. 4, pp. 1531-1539, 1996.

[62] M. Monif, C. A. Reid, K. L. Powell, M. L. Smart, and D. A. Williams, "The $\mathrm{P} 2 \mathrm{X}_{7}$ receptor drives microglial activation and proliferation: a trophic role for P2X7R pore," Journal of Neuroscience, vol. 29, no. 12, pp. 3781-3791, 2009.

[63] R. Bartlett, J. J. Yerbury, and R. Sluyter, "P2X $\mathrm{X}_{7}$ receptor activacion induces reactive oxygen species formation and cell death in murine EOC13 microglia," Mediators of Inflammation, vol. 2013, Article ID 271813, 18 pages, 2013.

[64] J. Kang, N. Kang, D. Lovatt et al., "Connexin 43 hemichannels are permeable to ATP," Journal of Neuroscience, vol. 28, no. 18, pp. 4702-4711, 2008.

[65] D. L. Beahm and J. E. Hall, "Opening hemichannels in nonjunctional membrane stimulates gap junction formation," Biophysical Journal, vol. 86, no. 2, pp. 781-796, 2004.

[66] A. J. Siller-Jackson, S. Burra, S. Gu et al., "Adaptation of connexin 43-hemichannel prostaglandin release to mechanical loading," Journal of Biological Chemistry, vol. 283, no. 39, pp. 26374-26382, 2008.

[67] E. Decrock, M. Vinken, M. Bol et al., "Calcium and connexinbased intercellular communication, a deadly catch?" Cell Calcium, vol. 50, pp. 310-321, 2011.

[68] E. De Vuyst, N. Wang, E. Decrock et al., "Ca ${ }^{2+}$ regulation of connexin 43 hemichannels in C6 glioma and glial cells," Cell Calcium, vol. 46, no. 3, pp. 176-187, 2009.

[69] H. A. Sánchez, G. Meșe, M. Srinivas, T. W. White, and V. K. Verselis, "Differentially altered $\mathrm{Ca}^{2+}$ regulation and $\mathrm{Ca}^{2+}$ permeability in Cx26 hemichannels formed by the A40V and G45E mutations that cause keratitis ichthyosis deafness syndrome," Journal of General Physiology, vol. 136, no. 1, pp. 4762, 2010.

[70] K. A. Schalper, H. A. Sánchez, S. C. Lee, G. A. Altenberg, M. H. Nathanson, and J. C. Sáez, "Connexin 43 hemichannels mediate the $\mathrm{Ca}^{2+}$ influx induced by extracellular alkalinization," American Journal of Physiology, vol. 299, no. 6, pp. C1504-C1515, 2010.

[71] F. Vanden Abeele, G. Bidaux, D. Gordienko et al., "Functional implications of calcium permeability of the channel formed by pannexin 1," Journal of Cell Biology, vol. 174, no. 4, pp. 535-546, 2006.

[72] A. Mendoza-Naranjo, P. J. Saéz, C. C. Johansson et al., "Functional gap junctions facilitate melanoma antigen transfer and cross-presentation between human dendritic cells," Journal of Immunology, vol. 178, no. 11, pp. 6949-6957, 2007.

[73] K. S. Ásgeirsson, K. Ólafsdóttir, J. G. Jónasson, and H. M. Ógmundsdóttir, "The effects of IL- 6 on cell adhesion and Ecadherin expression in breast cancer," Cytokine, vol. 10, no. 9, pp. 720-728, 1998.

[74] M. Tsuda, T. Masuda, J. Kitano, H. Shimoyama, H. TozakiSaitoh, and K. Inoue, "IFN- $\gamma$ receptor signaling mediates spinal microglia activation driving neuropathic pain," Proceedings of the National Academy of Sciences of the United States of America, vol. 106, no. 19, pp. 8032-8037, 2009.

[75] T. Takenouchi, S. Sugama, Y. Iwamaru, M. Hashimoto, and H. Kitani, "Modulation of the ATP-lnduced release and processing 
of IL-1B in microglial cells," Critical Reviews in Immunology, vol. 29, no. 4, pp. 335-345, 2009.

[76] J. M. Garré, M. A. Retamal, P. Cassina et al., "FGF-1 induces ATP release from spinal astrocytes in culture and opens pannexin and connexin hemichannels," Proceedings of the National Academy of Sciences of the United States of America, vol. 107, no. 52, pp. 22659-22664, 2010.

[77] S. Iwabuchi and K. Kawahara, "Functional significance of the negative-feedback regulation of ATP release via pannexin-1 hemichannels under ischemic stress in astrocytes," Neurochemistry International, vol. 58, no. 3, pp. 376-384, 2011.

[78] D. Sieger, C. Moritz, T. Ziegenhals, S. Prykhozhij, and F. Peri, "Long-range $\mathrm{Ca}^{2+}$ waves transmit brain-damage signals to microglia," Developmental Cell, vol. 22, pp. 1138-1148, 2012.

[79] C. Rigato, N. Swinnen, R. Buckinx et al., "Microglia proliferation is controlled by $\mathrm{P} 2 \mathrm{X} 7$ receptors in a Pannexin1-independent manner during early embryonic spinal cord invasion," The Journal of Neuroscience, vol. 32, pp. 11559-11573, 2012.

[80] R. A. Quintanilla, J. A. Orellana, and R. von Bernhardi, "Understanding risk factors for Alzheimer's disease: interplay of neuroinflammation, connexin-based communication and oxidative stress," Archives of Medical Research, vol. 43, pp. 632644, 2012. 


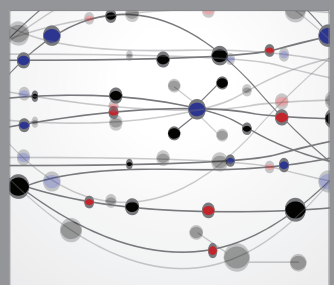

The Scientific World Journal
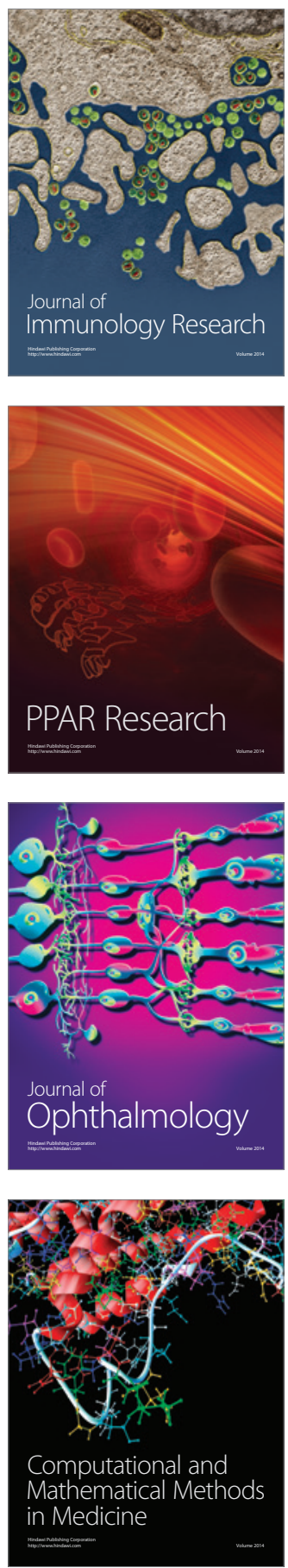

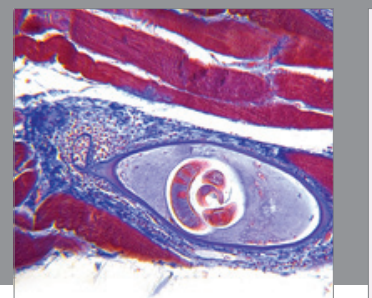

Gastroenterology

Research and Practice
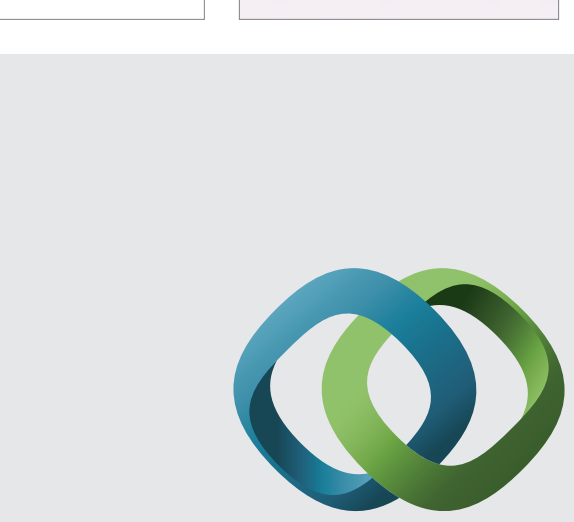

\section{Hindawi}

Submit your manuscripts at

http://www.hindawi.com
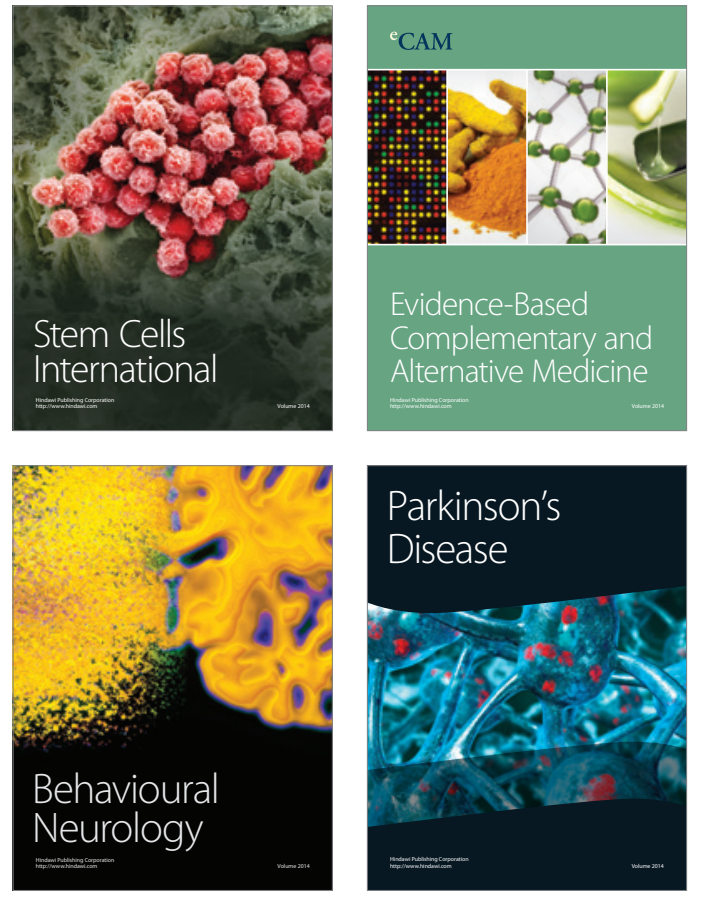
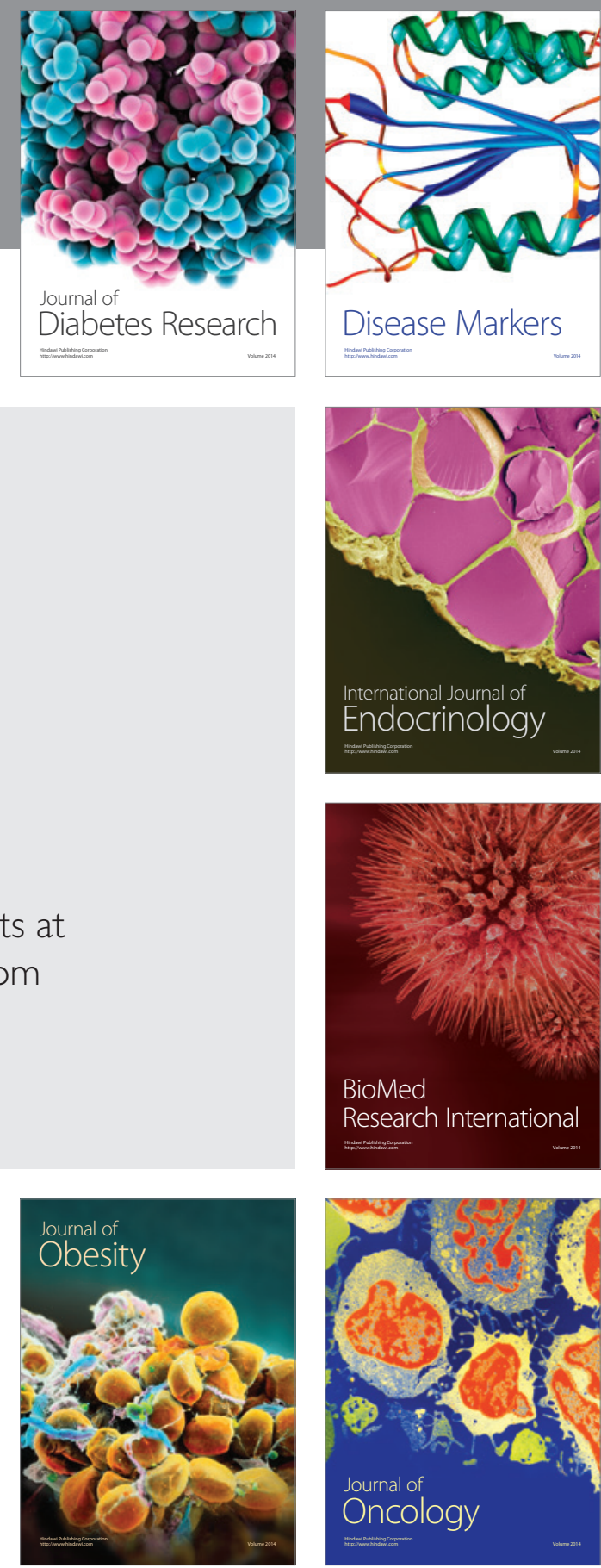

Disease Markers
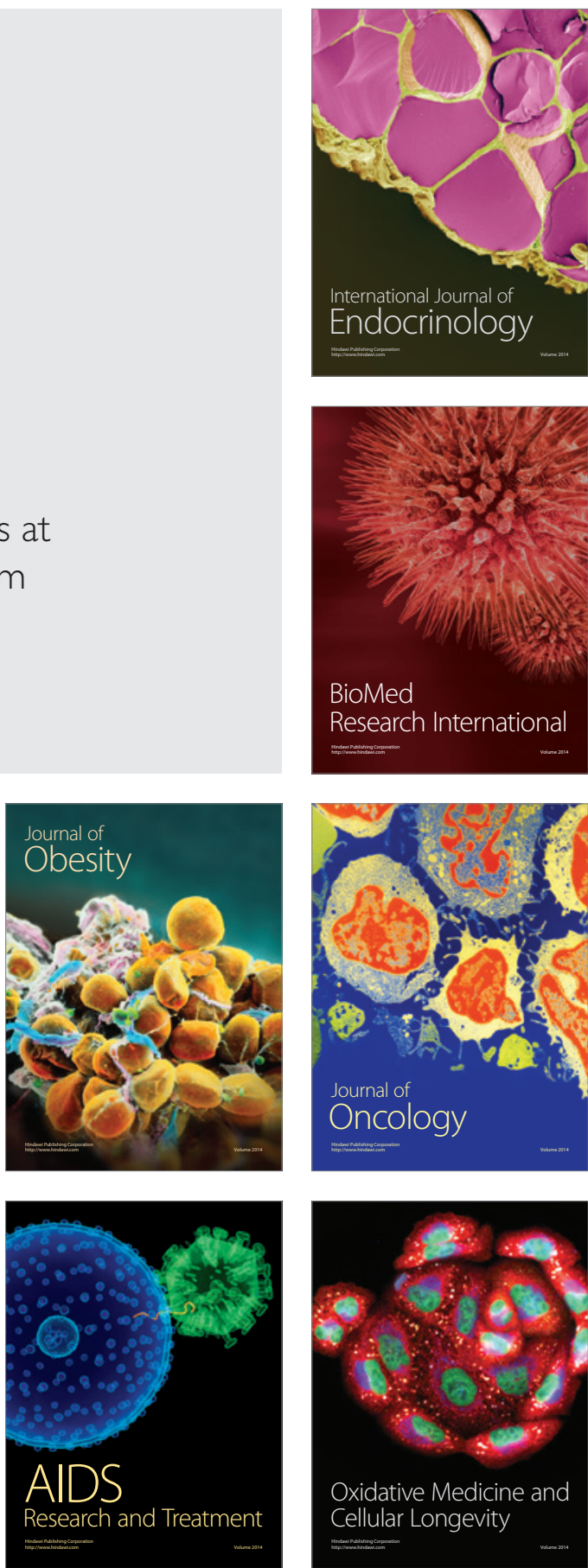